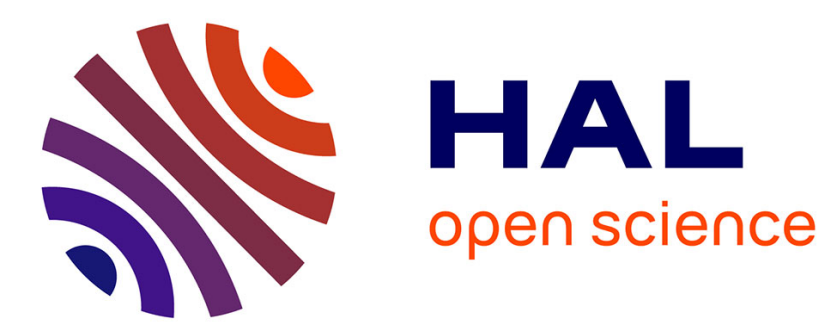

\title{
Cherries for sale: The incidence and timing of cross-border M\&A
}

\author{
Bruce A. Blonigen, Lionel Fontagné, Nicholas Sly, Farid Toubal
}

\section{To cite this version:}

Bruce A. Blonigen, Lionel Fontagné, Nicholas Sly, Farid Toubal. Cherries for sale: The incidence and timing of cross-border M\&A. Journal of International Economics, 2014, 94 (2), pp.341-357. 10.1016/j.jinteco.2014.08.005 . hal-01299761

\section{HAL Id: hal-01299761 https://hal.science/hal-01299761}

Submitted on 8 Apr 2016

HAL is a multi-disciplinary open access archive for the deposit and dissemination of scientific research documents, whether they are published or not. The documents may come from teaching and research institutions in France or abroad, or from public or private research centers.
L'archive ouverte pluridisciplinaire HAL, est destinée au dépôt et à la diffusion de documents scientifiques de niveau recherche, publiés ou non, émanant des établissements d'enseignement et de recherche français ou étrangers, des laboratoires publics ou privés. 


\title{
Cherries for Sale: The Incidence and Timing of Cross-Border M\&A
}

\author{
Bruce A. Blonigen ${ }^{\mathrm{a}}$, Lionel Fontagné ${ }^{\mathrm{b}}$, Nicholas Sly ${ }^{\mathrm{c}}$, Farid Toubal ${ }^{\mathrm{d}}$ \\ ${ }^{a}$ Department of Economics, University of Oregon, Eugene, OR 97403-1285 and NBER \\ ${ }^{b}$ Maison des Sciences Economiques, 106-112 Bd de l'Hôpital, 75647 Paris Cedex 13 \\ ${ }^{c}$ Department of Economics, University of Oregon, Eugene, OR 97403-1285 and CESifo \\ ${ }^{d} 61$, avenue du Prsident Wilson, Bat Cournot, Office 503. 94235 Cachan cedex, France.
}

\begin{abstract}
This paper develops a model of cross-border M\&A activity that features firm-level productivity shocks and endogenous export activity. We show that foreign firms will be relatively more attracted to targets in the domestic country that had high productivity levels that induced them to invest in large export networks several years prior to acquisition, but subsequently experienced a negative productivity shock (i.e., cherries for sale). From the theory we derive a dynamic panel binary choice empirical model to predict cross-border M\&A activity, and find strong evidence for our hypotheses connecting the evolution of firm-level productivity to the ultimate targets of crossborder acquisitions using French firm-level data.
\end{abstract}

Keywords: Foreign Direct Investment, Productivity, Export Networks

JEL Classification: F2, L1

\section{Introduction}

A significant majority of foreign direct investment (FDI), especially between developed countries, is in the form of cross-border merger and acquisition (M\&A) activity. ${ }^{1}$ This fact suggests that FDI flows across countries, and their subsequent economic effects, are significantly related to the choice of multinational enterprises to acquire target firms with specific characteristics. Once target

\footnotetext{
${ }^{2}$ The authors owe many thanks to seminar participants at the NBER ITI Spring Meeting 2012, Gep-ifo conference on International Trade, Productivity and Factor Movements at CESifo, University of British Columbia, Brown University and the Banque de France, UC-Irvine, Indiana University, Shanghai University of Finance and Economics, Tsinghua University. Farid Toubal would like to thank the CEPR project "Globalization Investment and Services Trade" funded by the European Commission under FP7-PEOPLE-ITN-2008-21. The authors are responsible for remaining errors.

Email addresses: bruceb@uoregon. edu (Bruce A. Blonigen), Lionel.Fontagne@univ-paris1.fr (Lionel Fontagné), sly@uoregon.edu (Nicholas Sly), ftoubal@ens-cachan.fr (Farid Toubal)

${ }^{1}$ For example, UNCTAD (2000) reports that the total value of cross-border M\&A constitutes more that $80 \%$ of total global FDI flows.
} 
firms have been acquired by multinationals, a significant majority of affiliate production is exported to nearby countries, which suggests that export networks are among the key features of target firms sought by multinational enterprises. In this paper we develop a model of cross-border M\&A that features firm-level productivity shocks and endogenous export behavior among target firms. From the model we derive a dynamic binary choice model, which exploits the autoregressive nature of firm productivity levels and sunk investments in their export activity, to predict cross-border M\&A flows. Using administrative data from a panel of French firms we find strong evidence that export activities promote takeover by foreign multinational firms, and that productivity shocks within target firms are linked to the timing at which these cross-border acquisitions take place.

There is nascent international trade literature that, like this study, views the cross-border acquisition decision as being motivated by the matching of complementary assets between multinational and domestic firms (e.g., Nocke and Yeaple (2007;2008), Head \& Ries (2008), and Guadalupe et al. (2012)); although Neary (2007) alternatively views cross-border M\&A activity as being motivated by market power considerations. ${ }^{2}$ While this literature has provided important contributions to our growing knowledge about cross-border M\&A activity, a common feature of these prior studies is that they are static, with firm characteristics being fixed over time. Failing to recognize that the assets firms possess evolve over time omits important information about the incentives of target firms to accept current takeover bids. Moreover, because changes in target firm productivity are likely to be correlated with the state of the targets' other assets (e.g., the skills of workers/managers

\footnotetext{
${ }^{2}$ Nocke and Yeaple $(2007 ; 2008)$ provide a general equilibrium framework characterizing the matching of mobile and non-mobile assets that occurs in a world of cross-border M\&A. Nocke \& Yeaple (2007) shows that whether cross-border M\&A activity involves the least or most efficient firms in the economy depends on whether there is heterogeneity across firms in their mobile assets (such as productivity) or immobile, location-specific assets (such as local distribution capabilities). The analysis in Nocke \& Yeaple (2008) focuses on the choice between greenfield and cross-border M\&A as the mode of FDI, with theory and evidence from U.S. data that the most productive firms choose greenfield over cross-border M\&A. Head \& Ries (2008) develop a model matching between managers and productive assets in a multi-country world. Their framework explains well the strong gravity relationships in crossborder and FDI data, as large countries have more managers and firm assets to match, while greater distances make it more difficult for managers to monitor operations of those assets. In Guadalupe et al. (2012), target firms' productive capabilities complement new investments by multinationals and these assets are match via acquisition, as is evidenced in Spanish data. As an alternative to asset-matching models, Neary (2007) provides a general equilibrium model where oligopolistic firms pursue cross-border M\&A activity in the pursuit of increased market power. The paper shows that cross-border M\&A activity can be spurred from trade liberalization as firms in countries where their sector has a comparative advantage acquire firms in countries where their sector has a comparative disadvantage.
} 
employed or their ability to integrate the acquiring firm's technological investments), the omission of firm-level productivity shocks can generate substantial bias when estimating cross-border M\&A activity. Another common view held in asset matching models of cross-border M\&A is that the relevant target firm characteristics are specific to either the target or acquiring firm's home market. However, Hanson et al. (2001) provide broad evidence that affiliates export a significant portion of total sales to nearby countries, so that the ability of targets to enter proximate markets can also have a substantial impact on acquisition activity. ${ }^{3}$ Again, the propensity of firms to export is tightly linked to other assets, such as their productivity level, revenue, or skill intensity (Bernard \& Jensen (1999)). Thus ignoring the endogenous decision of target firms to export may introduce substantial bias when estimating cross-border M\&A activity.

In this paper we develop a three-stage model where firms have varying capabilities to make (sunk) investments in export networks and face possible future shocks to their physical productivity. In the first stage, each firm receives a random draw of its productivity, as well as its capability to set up export networks. Based on these draws, firms then select the foreign markets, if any, to which they will export, and incur substantial sunk (or beachhead) costs to establish their export network. In stage 2, firms realize persistent productivity shocks, which can then alter how much the firm values the option of continuing to sell goods on its established export network independently. In the final stage, firms participate in an M\&A market, where domestic targets are acquired based on both their current capabilities, changes in productivity, and the previously established export network.

Modeling a multi-period environment with firm-specific shocks to their capabilities allows us to predict not only which firms are acquired, but also the timing of the acquisition. Furthermore, export networks established by domestic targets are likely to differ from those established by foreign acquirers due to locational differences, and are, therefore, of relatively high value to a foreign firm. ${ }^{4}$ Other domestic firms are less likely to value targets with large export networks, because

\footnotetext{
${ }^{3}$ We note that the acquisition of export-networks via cross-border M\&A is consistent with prior evidence that a significant share of worldwide FDI activity is by export-platform motives (Blonigen et al. (2007) and Ekholm et al. (2007)).

${ }^{4} \mathrm{An}$ equivalent interpretation is that established export networks are endogenously determined sources of (trade) cost synergies between firms in different locations.
} 
they will independently establish similar export networks due to their identical location; redundancy makes the target firm's export networks relatively less valuable to domestic acquirers as it is to foreign firms. Thus, we are able to predict which targets are more likely candidates for cross-border M\&A, as opposed to domestic acquisition.

To empirically assess the role of changes in firm characteristics and export activity in promoting cross-border acquisitions, we examine our model's hypotheses using detailed administrative data on French manufacturing firms from 1999-2006. We use the theoretical model of endogenous export behavior and cross-border M\&A to derive a dynamic panel binary choice model that predicts which targets are acquired by multinationals as their characteristics change over time. An important feature of the empirical model is that it circumvents the initial conditions problem associated with estimating the likelihood of acquisition when firm-specific sunk costs to enter foreign markets are unobserved, and the target firm's initial level of productivity corresponds to a time period that may predate the sample period. Each target firm chooses where to export conditional on its own costs to enter foreign markets and productivity, in anticipation of productivity shocks and the likelihood of being acquired by a foreign firm. Thus, we incorporate a measure of previously observed investments in developing export networks, which is conditional on the unobserved firmspecific sunk costs to access foreign markets and previous levels of firm productivity. We then exploit the autoregressive nature of firm-level productivities to derive an empirical strategy that avoids the biases associated with estimating the likelihood of acquisition where previous levels of firm productivity are observed, but perhaps not the initial level of firm productivity, and there are correlated unobserved effects. ${ }^{5}$ Consistent with the predictions of the theoretical model, we find robust evidence that the decision to export to multiple countries, and recent negative productivity shocks, both significantly increase the likelihood that a domestic target firm is acquired by a foreign multinational. We also show that the export network effect is larger when foreign firms differ more in their locational costs from the target, as there will then be less overlap in the networks independently established by the acquirer and target, making the export network of the target more

\footnotetext{
${ }^{5}$ See Arellano \& Carrasco (2003), Wooldridge (2005), and Honore \& Tamer (2006) for detailed discussions about the initial conditions problem associated with estimating non-linear dynamic panel data models with unobserved effects. Our derived estimation strategy is closely related to those studied in Honore \& Lewbel (2002).
} 
valuable to the acquirer.

Concerning the specific assets that acquirers seek, the classic notion in the finance literature is that M\&A activity is one of natural selection, as well-performing firms take over the assets of poorly-performing firms (e.g., Manne (1965)). Consistent with this view, Lichtenberg \& Siegel (1987) find evidence that "lemons" (i.e., poorly performing firms) are the primary targets in U.S. acquisitions in manufacturing. Several existing models of cross-border M\&A also often predict that "lemons" will be targets, including the M-industry model in Nocke \& Yeaple (2007) and in Neary (2007). However, recent empirical evidence suggests that acquiring firms, especially foreign firms, are acquiring highly productive "cherries." This has been found using data from Chile (Ramondo (2009)), Indonesia (Arnold \& Javorcik (2009)), the U.S. (Criscuolo \& Martin (2009)), and Spain (Guadalupe et al. (2012)). The multi-period aspect of our model allows us to reconcile this seemingly opposing evidence by showing that "cherry" or "lemon" effects actually refer to the value of target firm assets at different states over time. We show that multinationals seek valuable assets among targets (export networks) that can be acquired when the price is relatively low (after a negative productivity shock). That is, they seek "cherries for sale."

There is also a small recent finance literature modeling a variety of motivations for general M\&A activity (domestic or cross-border). Rhodes-Kropf \& Robinson (2008) is a classic model of positive assortative matching of assets and Maksimovic \& Phillips (2009) shows how differential demand shocks across sectors alters firms decisions to acquire/own assets across these sectors. Gorton et al. (2009) illustrates why firms may strategically grow through acquisitions of smaller firms to avoid being acquired, and develops a model where firms adjust their optimal assets (presumably through M\&A activity) in response to industry-level productivity shocks. As we do here, Yang (2008) highlights the importance of firm-level versus aggregate shocks in promoting acquisition activity; she calibrates the model to correspond to moments in US acquisitions data, and examines how firms can grow or downsize through acquisition activity. Our analysis is distinct in that we are able to solve explicitly for equilibrium M\&A activity, and derive an empirical specification that predicts M\&A activity from firm and industry characteristics, particularly when there may be important unobserved firm-level characteristics. Furthermore, our multi-country frame- 
work with endogenous investments in export networks allows us to separately predict cross-border versus domestic M\&A.

In summary, our paper provides three main contributions to the literature. First, we build a simple multi-period model of M\&A that shows how firm-level shocks promote acquisition activity, and how accounting for these shocks provides a potential resolution to the inconsistent cherries and lemons distinction found in the prior literature. Second, we incorporate endogenous export activity among target firms to show, both theoretically and empirically, the large and crucial role played by export networks in promoting cross-border M\&A activity. Finally, we show how one can condition on realizations of past export behavior and productivity shocks to overcome the initial conditions problem associated with estimating non-linear dynamic panel data models of M\&A activity with correlated unobserved effects.

In the next section, we provide some basic descriptive statistics and figures of cross-border M\&A activity using detailed firm-level data from France. Even these simple graphs demonstrate strong evidence that multinationals seek targets that are "cherries for sale." In Sections 3, 4, and 5, we provide theory to explain these patterns more formally. In Section 6 we derive our empirical framework from the theory to predict the likelihood of foreign acquisition. Section 7 describes our sample compiled from several sources of administrative data on French firms. The results of our empirical analysis are in Section 8 , followed by concluding remarks.

\section{A First Look at the Patterns in the Data}

In this section, we provide descriptive statistics on the level, and evolution, of productivity and export networks of French firms that are acquired by foreign multinationals. The sample for our analysis is built from several micro-datasets that are provided by different French administrations and covers the period from 1999-2006. These data are matched using the firm tax-register number which identifies each unique firm located in France.

We identify firms involved in a merger or acquisition using the 'extended' LIFI (LIaison FInancière) data, a dataset that has information on the ownership and nationality of the parent com- 
Figure 1: Target Productivity and Export Networks Margins Across Time
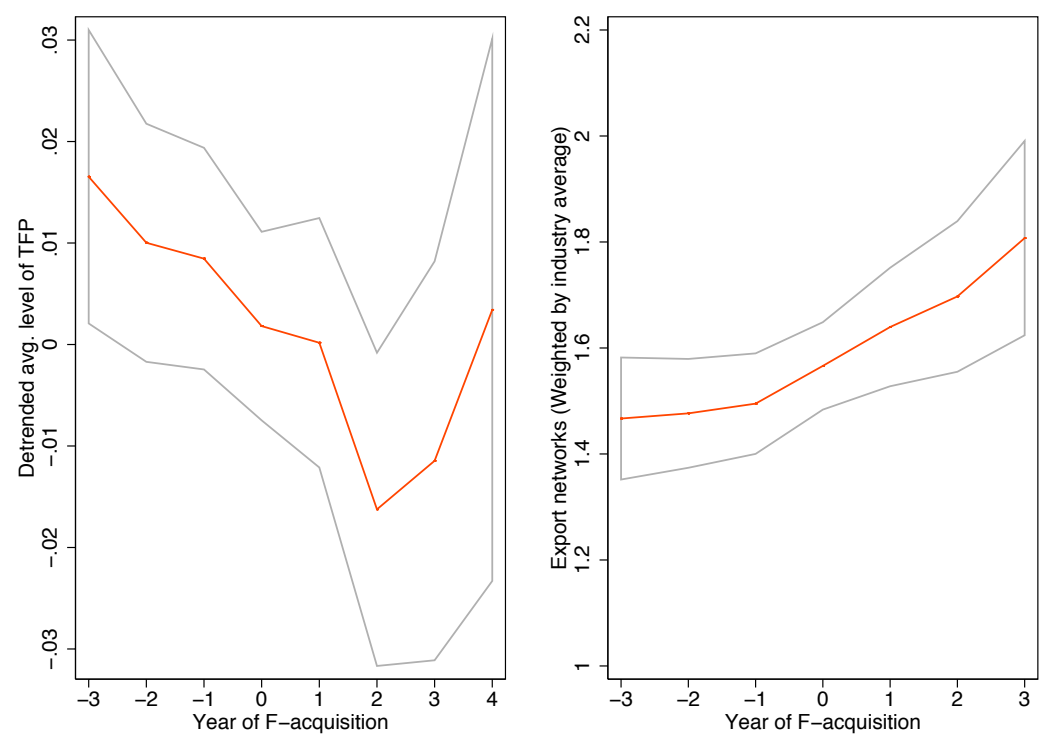

Source: Authors calculations based on "LIFI" and "EAE" data.

pany of firms located in France. ${ }^{6}$ We use LIFI to identify the year of a takeover and the foreign status of the acquiring firm. We define a firm as having undergone a foreign M\&A if the owner in time $t$ is foreign, while the owner in $t-1$ is French. Similarly, a firm undergoes a domestic M\&A if it changes ownership but the owner remains French.

To calculate firm-level TFP, we first merge the LIFI data to the EAE (Enquete Annuelle d'Entreprise) annual business survey dataset, which contains information from firms' income statements and balance sheets. It also reports the location of firms in France and their 4-digit sector of principal activity. The survey has information on firms with more than 25 employees. Importantly, the EAE dataset is exhaustive above this reporting threshold. In order to compute total factor productivity (TFP), we restrict the data to the manufacturing sectors. We compute firm-level TFP using the pro-

\footnotetext{
${ }^{6} \mathrm{~A}$ firm classified as French independent is a resident in France and is not owned by a group. A French affiliate is resident in France and owned by a French parent. A foreign affiliate is a firm that is located in France but owned by a foreign group. An affiliate is foreign owned if the foreign firm controls more than $50 \%$ of its shares or voting rights. The results are insensitive to the specified cutoff for an acquisition to take place, as the median share of voting shares owned by a group is $99 \%$.
} 
cedure described by Olley \& Pakes (1996), controlling for the simultaneity bias that arises from the endogeneity of a firm's input selection. We then calculate a firm's detrended TFP relative to its sectoral average. Note that we find similar patterns among target firms when considering other measure of firms' technical capabilities such as market share. ${ }^{7}$

The left panel of Figure 1 plots normalized detrended TFP for the French firms acquired by foreign owners from three years prior to the acquisition through four years after the acquisition. The middle line shows the relative detrended TFP for the average French firm acquired by a foreign owner, whereas the lines above and below show the relative detrended TFP for the 95th and 5th percentile, respectively. The pattern is striking and consistent with a "for sale" effect. Relative detrended TFP is falling significantly in the three years prior to acquisition for French firms who are acquired by foreign firms. The average acquired firm falls from being $1.5 \%$ above the mean of all firms in its sector to being just an average firm in its sector at the time of acquisition. By way of comparison, the $1.5 \%$ reduction in productivity for the typical acquisition target corresponds to approximately $1 / 16$ of a standard deviation of the observed year-to-year changes in firm-level TFP. In other words, the decline in productivity among acquisition targets are significant and widespread, but not driven by outliers in terms of the magnitude of firm-level shocks.

The other important feature of the data is that the acquired French firms (from as low as the 5th percentile) all have an above-average relative detrended TFP in the third year before the acquisition; i.e., these acquired firms are "cherries," in the initial TFP dimension. In years prior to acquisition, targets of multinational takeovers had high productivities that endow them with relatively strong incentives to invest in valuable assets, such as export capacity. In our model below, and consistent with well-known stylized facts, high TFP levels allow a firm to profitably export to many destinations. The right panel of Figure 1 illustrates the corresponding export networks established by firms acquired during the sample period. Information about firm-level trading behavior, which we use to construct our variable related to export networks, is taken from the French customs (Douanes). We observe the yearly value of exports of each firm at the product-level, in each

\footnotetext{
${ }^{7}$ In Section 8.3 we replicate our main results using observed firm-level market share in place of estimated firm-level TFP.
} 
destination market. ${ }^{8}$ A target firm's export network is defined as the number of unique countries served.

The pattern of the export networks established by French firms who are acquired by foreign firms further reinforces the evidence that acquired targets are cherries in the dimension of export networks, as the average firm has an export network that is 40-50\% larger than its sector's average in the years leading up to the foreign acquisition. Again, the lines above and below report the statistic for the 95th and 5th percentile of the sample, respectively. Even the 5th percentile target in the sample has an export network that is well above its own sector's average. Note that even as the productivity of target firms falls, as seen in left panel of Figure 1, we see in the right panel that the export networks of target firms remain stable prior to acquisition. This fact suggest that the costs to begin exporting to a new market are in part sunk, and that an export network is maintained even as firm productivity falls. While we have only used the number of country links as our measure of export networks, qualitatively identical patterns are in the data when we measure exports by number of exported products or exported country-product combinations. However, in the statistical analysis below, we will show that country links are the main driver in our export network effects.

While this paper's focus is on who gets acquired and when, there are interesting patterns of TFP and export networks after foreign acquisition in our sample. Firm-level TFP continues to fall in the first years after the acquisition and then rebounds, and for the majority of firms, improves significantly three and four years later. Export networks begin to increase for the target firm immediately after the acquisition. The fall in firm TFP in the first years after acquisition, with growth in the number of export destinations, and increase in productivity after acquisition, are each consistent with the evidence in Guadalupe et al. (2012), where acquiring firms make costly ex post investments in the target's production technology and export capacity.

Our goal in the remainder of the paper is to develop a model of exporting and M\&A behavior that is consistent with the patterns in Figure 1, and to derive an empirical strategy that demonstrates how acquisition activity is motivated by export networks and productivity changes.

\footnotetext{
${ }^{8}$ We use the 8-digit Combined Nomenclature, a European extension of the 6-digit Harmonized System. We have approximately 200 possible destinations and 8,000 different product categories.
} 


\section{Model}

We build a model of a multi-country world with differentiated producers from each country operating in a single sector. The timing of the model occurs in three stages. In stage one, firms are born with a specific productivity, and then choose whether or not to make investments that allow them to export to foreign markets. The multi-country trading environment builds from Helpman et al. (2008), with firm-specific sunk costs to enter foreign markets as in Impullitti et al. (2013). In stage 2 , domestic firms realize a permanent shock to their productivity. We then focus on a single country, and examine M\&A activity. In stage 3, target firms are bought and sold in the domestic M\&A market, including the possibility that foreign multinationals acquire domestic firms. Our goal is to demonstrate how the export networks established in stage 1, and the realization of productivity shocks among firms in stage 2, influence cross-border M\&A activity in stage 3.

\section{Basics: Consumption $\mathcal{E}$ Production}

The world is comprised of a mass of countries indexed by $j \in[1, J]$. There is a continuum of products in each country, and the representative consumer in each country $j$ has the following utility function:

$$
U=\ln \left[\int_{l \in B_{j}} x_{j}(l)^{(\epsilon-1) / \epsilon} d l\right]^{\frac{\epsilon}{\epsilon-1}}, \epsilon>1,
$$

where $x_{j}(l)$ is the consumption of product $l, B_{j}$ is the set of products available for consumption in country $j$, and $\epsilon$ is the elasticity of substitution across varieties, which is common across countries. Letting $E_{j}$ denote the expenditure (or income) level of country $j$, its demand for product $l$ is derived as

$$
x_{j}(l)=\frac{p_{j}(l)^{-\epsilon} E_{j}}{P_{j}^{1-\epsilon}},
$$

where $p_{j}(l)$ is the price of product $l$ in country $j$, and $P_{j}$ is the country's ideal price index, defined as 


$$
P_{j}=\left[\int_{l \in B_{j}} p_{j}(l)^{1-\epsilon} d l\right]^{1 /(1-\epsilon)} .
$$

Each country has a mass $M_{j}$ of risk-neutral firms, each producing a unique variety in a monopolisticallycompetitive sector. The cost of producing a unit of output for a firm in country $j$ is $c_{j} a$, where $a$ is a firm-specific measure of the number of bundles of the country's inputs required during production, and $c_{j}$ is a country-specific measure of the cost of this bundle. The inverse of $a$ represents the firm's productivity level. Each country has an identical cumulative distribution function $G_{a}(a)$, with support $\left[a_{L}, a_{H}\right]$, that describes the distribution of productivity across firms.

\subsection{Stage 1: Export networks}

In order for a firm in country $j$ to sell its product in country $i \neq j$, it must incur both a one-time sunk cost, $f_{i j}$, and a trade cost, $\tau_{i j}$, that are specific to the $i j$ country pair. For convenience, we normalize $f_{j j}=0$ for each country $j$. The sunk nature of investments to enter foreign markets is consistent with Impullitti et al. (2013), as well as the broad evidence of persistence in export behavior among firms; see Bernard \& Jensen (2004) for evidence from the US, Campa (2004) for evidence from Spain, Bernard \& Wagner (2001) for evidence from Germany. ${ }^{9}$

Within each country, firms differ in their ability to establish export networks. The sunk costs are given in terms of the amount of domestic factors that must be hired at costs $c_{j}$, where $b f_{i j}$ is the total number of domestic factors that must be hired by a firm with parameter $b$ in country $j$ in order to serve country $i$. Let $G_{b}(b)$, be the distribution of the firm-specific parameter that determines the cost to set up export networks, having support $\left[b_{L}, b_{H}\right]$. This additional source of firm-level heterogeneity is motivated by several empirical facts. Roberts \& Tybout (1997) provide evidence that plant-level export behavior over time is consistent with the presence of sunk costs to enter foreign markets, and that there is substantial heterogeneity in these sunk costs across establishments. Foster et al. (2008) have shown that there is an important distinction between firms'

\footnotetext{
${ }^{9}$ We abstract from fixed costs of exporting that may need to be incurred after export networks have been established. We note that, conditional on the at least some of the setup costs for exporting being sunk, none of our results are affected by the possibility of additional recurring fixed costs of exporting in each period. We assume per period fixed costs are zero solely to ease the exposition of the model.
} 
technical productivity and their ability to profitably serve a market when considering firm exit and entry across time. And finally, Bernard et al. (2003) provide broad evidence that there is significant overlap in the distribution of productivities across exporting and non-exporting plants, suggesting additional fixed characteristics of firms influence their decision to sell to foreign markets. ${ }^{10}$

Generally we are agnostic about whether firm productivity parameters, $a$, and the firm-specific parameter affecting the costs to export, $b$, are drawn independently. We are interested in the conditional likelihood of acquisition given target firm characteristics, and so all our theoretical results are maintained regardless of the joint distribution of firm productivity and export costs parameters. Yet, a key focus of our analysis will be to use the model to derive an empirical strategy that generates consistent estimates of how target firm characteristics impact M\&A activity, even if there is correlation between the initial draws of productivity and market access costs among firms.

We assume that transport costs are of the iceberg variety, where $\tau_{i j}$ units of a product must be shipped from country $j$ in order for one unit of the product to arrive in country $i$, and $\tau_{i j}>1$ for $i \neq j$ and $\tau_{j j}=1$ for each country $j$. For each country $j$, we order the set of potential export destinations in terms of their relative trade costs, $c_{j}^{\epsilon} f_{i j} \tau_{i j}^{\epsilon-1}$, and denote this set as $\mathcal{D}_{j} \subset[1, J]$. We note for the reader that we are departing from Helpman et al. (2008) in specifying the costs to gain access to market $i$ as a one-time sunk cost, rather than a recurring per-period fixed cost. Define $N_{j}(a, b) \subset \mathcal{D}_{j}$ as the endogenously determined set of destinations that a firm with characteristics $(a, b)$ in country $j$ chooses to serve, which we call its export network.

Given a continuum of monopolistically-competitive firms, each producing a distinct variety, we derive the standard price mark-up for a firm producing in country $j$ with productivity parameter $a$ and selling in country $i$ so that the price of variety $l$ is given by $p_{j}(l)=\tau_{i j} \frac{\epsilon c_{j} a}{\epsilon-1}$. From this, we can write the operating profit a firm in country $j$ receives from its sales of variety $l$ to consumers in country $i$, that have total expenditures $E_{i}$, conditional on its productivity parameter $a$, as

\footnotetext{
${ }^{10}$ Note that with CES preferences in all markets, lower firm-specific costs to enter each market is equivalent to firms being able to sell proportionately more output in each market. In this sense, the second source of firm heterogeneity represents variations target firms' abilities to profitably operate in foreign markets. Syverson (2004) argues that their is an important distinction between physical productivity and the ability to sell in a particular market, which further motivates our inclusion of two distinct sources of firm-level heterogeneity.
} 


$$
\pi_{i j}^{l}(a)=\frac{E_{i}}{\epsilon}\left(\frac{\tau_{i j} c_{j} a}{P_{i}}\right)^{1-\epsilon} .
$$

\subsection{Stage 2: Shocks in firm productivity}

After firms have incurred the sunk costs to establish their trade networks they are all subject to persistent productivity shocks, $1 / \psi$, which are infinitesimal and independent of their initial productivity level. Equivalently, a firm with initial productivity parameter $a$ continues to operate with productivity parameter $a \psi$, once its shock is realized. We assume that (log) firm productivities evolve according to a random walk such that the productivity shocks $\ln (1 / \psi)$ are distributed lognormal, with drift $\omega$ and variance $\sigma$. Upon realizing a productivity shock, firms maintain their export network established in stage $1, N_{j}(a, b)$. The profit a firm earns by operating independently across its entire export network once its productivity shock is realized is

$$
V_{j}(a \psi)=\int_{i \in N_{j}(a, b)} \pi_{i j}^{l}(a \psi) d(i) .
$$

Put another way, equation (5) represents the outside option of a target firm on the M\&A market. For any acquisition price offered, a target maintains the option of serving markets $i \in N_{j}(a, b)$ with its realized productivity parameter $a \psi$.

\subsection{Stage 3: Merger $\mathcal{F}$ Acquisition}

Domestic firms can sell their assets, including access to foreign consumers via their established trade networks, to both foreign and domestic acquirers. Upon acquisition of a firm, the acquirer can substitute its own productivity, $a^{\prime}$, for the realized productivity of the target firm, $a \psi \cdot{ }^{11}$ In addition to integrating technologies, once a merger is completed the acquiring firm can select the location of production. In particular, the acquiring firm chooses the source country for exports

\footnotetext{
${ }^{11}$ For notational convenience we have let the acquiring firm substitute its own productivity for that of the target firm such that $a^{\prime}>a \psi$, consistent with the evidence in Nocke \& Yeaple (2008) that it is relatively high productivity and high revenue firms that select into cross-border acquisition activity. We note however that we impose no such restriction and impose no assumption generally about the relative productivity of targets and acquirers; for any meeting between firms the highest level of productivity is substituted for the lower. Writing instead that firms substitute $\max \left\{a^{\prime}, a \psi\right\}$ would be overly cumbersome.
} 
that minimizes variable trade costs. Denote $s_{i}^{j h}$ as the source of production that minimizes the transportation cost of serving market $i \in N_{j}(a, b) \cap N_{h}\left(a^{\prime}, b^{\prime}\right)$. The integration of the acquiring firm's technology, and the relocation of production within the merged firm, require fixed costs given by $I .{ }^{12}$ The probability of meeting a potential acquirer during any particular time period is given by the parameter $\mu .^{13}$

Upon acquisition, the merged firm produces two unique varieties that can be sold on the export networks established by the acquirer and target. For any potential target with initial productivity $a$, and trade network $N_{j}(a, b)$, an acquisition by a firm having productivity $a^{\prime}$ from county $h$ with export network $N_{h}\left(a^{\prime}, b^{\prime}\right)$ will create a conglomerate earning total operating profits

$$
Z_{j h}\left(a^{\prime}, b^{\prime}, a, b\right)=\int_{N_{j}(a, b) \cup N_{h}\left(a^{\prime}, b^{\prime}\right)}\left[\pi_{i s_{i}^{j h}}^{l}\left(a^{\prime}\right)+\pi_{i s_{i}^{j h}}^{m}\left(a^{\prime}\right)\right] d(i)
$$

There are two potential sources of surplus generated by a merger present in $Z_{j h}\left(a^{\prime}, b^{\prime}, a, b\right)$. The first is the profit earned by continuing to sell the acquiring and target firms' varieties on their existing networks, but from the least costly source of production, $s_{i}^{j h}$. If either variety can be relocated to a less costly production origin, then a merger generates a surplus through variable trade cost savings. The second potential source of surplus is the additional profits that can be earned by selling the target (acquiring) firm's product on the export network of the acquiring (target) firm that was otherwise not profitable to serve from their respective locations because of differences in fixed exporting costs. The gains from accessing new markets via cross-border M\&A are present for any pair of firms such that $N_{j}(a, b) \not \equiv N_{h}\left(a^{\prime}, b^{\prime}\right) .{ }^{14}$

\footnotetext{
${ }^{12}$ For now we specify the integration cost $I$ as being independent of target firm characteristics. Guadalupe et al. (2012) show that the investments acquirers make to update the target firm's production technology and export capacity following acquisition are complementary to its current productivity level. Also, Heyman et al. (2007) argue that integration of the acquiring firm technology is a skill-bias activity. We will account for these facts in the empirical analysis below.

${ }^{13}$ For simplicity we model the arrival rate of potential acquirers to be constant over time. Harford (2005) provides evidence that the timing of M\&A activity occurs in waves. We will account for the potential for the arrival rate of acquirers to be non-homogeneous in the empirical analysis below.

${ }^{14}$ Our primary goal is to highlight how export networks established by firms, and changes in their productivity, influence the likelihood of them being acquired by foreign firms. In doing so we have abstracted from strategic incentives to acquire competitors within imperfectly competitive markets. The combined profits earned by a merged firm over its different products may not be simply the sum of operating profits as in equation (6). An analysis of
} 


\section{Equilibrium}

In this section we derive conditions that characterize a Perfect Bayesian Equilibrium, such that firms in each country establish export networks in stage one, facing uncertainty about productivity shocks in stage two, and the potential for cross-border M\&A activity in stage three. We proceed using backwards induction.

\subsection{Equilibrium Acquisition Activity}

In stage three, firms engage in M\&A activity with the possibility that domestic targets are acquired by foreign multinationals. Let $Q_{j h}\left(a^{\prime}, b^{\prime}, a, b, \psi\right)$ be the strike price a firm with productivity given by $a^{\prime}$ in country $h$ pays to acquire a target firm with initial parameter $a$ and realized shock $\psi$ in country $j$, given their specific costs to establish export networks $b^{\prime}$ and $b$. The price of an acquisition is determined non-cooperatively and divides the surplus created by a merger, with a fraction $\beta$ retained by the acquirer and a fraction $1-\beta$ gained by the target firm. The probability that any acquisition takes place is then given by the likelihood that the value of the merged firm in (6), net the acquisition price, $Q_{j h}\left(a^{\prime}, b^{\prime}, a, b, \psi\right)$, is greater than the outside option of the target firm in (5). As our interest is in cross-border M\&A, we define the probability that a domestic firm with initial productivity $a$, and network cost parameter $b$, in country $j$ is acquired by a foreign firm from country $h$ at time $t$ as $Y_{j h t}(a, b)$, such that

$$
\begin{aligned}
Y_{j h t}(a, b)=\operatorname{Pr}\left[Z_{j h}\left(a^{\prime}, b^{\prime}, a, b\right)-Q_{j h}\left(a^{\prime}, b^{\prime}, a, b, \psi\right)-I-V_{h}\left(a^{\prime}\right)>\right. \\
\\
\left.Q_{j h}\left(a^{\prime}, b^{\prime}, a, b, \psi\right)-V_{j}(a \psi) \mid M_{h}, \mu\right],
\end{aligned}
$$

where $M_{h}$ is the mass of firms in country $h$, and $\mu$ is the probability that the target encounters a potential acquirer during time $t$.

Note that the surplus generated by a merger is strictly increasing in the productivity of the acquiring firm and strictly decreasing in the ability of the acquirer to establish its own export net-

strategic motivations for cross-border M\&A is provided by Neary (2007). While strategic incentives for mergers in an oligopolistic sector are outside the scope of this paper, we note that a merger is likely to consolidate market power, in addition to creating (trade) costs synergies. Thus we are likely to underestimate the probability of acquisition, rather than overstate the motives. 
works. Define $A_{j h}\left(b^{\prime}, a, b\right)$ as the productivity parameter of a firm in country $h$ that it is indifferent between acquiring and not acquiring a target with any realized productivity parameter $a$, specific export network costs $b$, in country $j$, given its own network costs $b^{\prime}$. That is, suppressing its arguments for simplicity, $A_{j h}$ satisfies

$$
\int_{N_{j}(a, b) \cup N_{h}\left(A_{j h}, b^{\prime}\right)}\left[\pi_{i s_{i}^{j h}}^{l}\left(A_{j h}\right)+\pi_{i s_{i}^{j h}}^{m}\left(A_{j h}\right)\right] d(i)
$$

$$
\equiv \int_{i \in N_{j}(a, b)} \pi_{i j}^{l}(a) d(i)+\int_{i \in N_{h}\left(A_{j h}, b^{\prime}\right)} \pi_{i j}^{m}\left(A_{j h}\right) d(i)+I
$$

We can now derive the likelihood of acquisition for any target firm. Let $M_{W}$ be the mass of firms worldwide, so that the probability that the acquirer that meets a domestic target is from country $h$ is given by $\frac{M_{h}}{M_{W}}$. The proportion of firms in country $h$ with productivity such that there is a non-negative surplus is generated by acquisition of firm $(a, b)$ in country $j$, given their own network costs, $b^{\prime}$ is given by $G_{a}\left(A_{j h}\left(b^{\prime}, a, b\right)\right)$. Finally, aggregating across the distribution of export network parameters of acquiring firms, the probability a target firm with realized productivity $a$ is acquired by a firm from country $h$ is

$$
Y_{j h t}(a, b)=\mu \frac{M_{h}}{M_{W}} \int_{b_{L}}^{b_{H}} G_{a}\left(A_{j h}\left(b^{\prime}, a, b\right)\right) d G_{b}\left(b^{\prime}\right) .
$$

Our analysis of cross-border M\&A activity will focus on the properties of equation (9), but we will first complete the characterization of equilibrium. ${ }^{15}$

\subsection{Equilibrium Target Firm Valuation with Productivity Shocks}

In the second stage, target firms face productivity shocks that affect the value of operating independently, and thereby the likelihood of accepting an offer to be acquired by another firm. Let $S_{j h}\left(a^{\prime}, b^{\prime}, a, b, \psi\right)$ be the surplus retained by a target $(a, b)$, which receives a shock $\psi$, in country $j$,

\footnotetext{
${ }^{15}$ From this point forward we suppress the arguments of $A_{j h}\left(b^{\prime}, a, b\right)$ for notational convenience.
} 
upon acquisition by a firm $\left(a^{\prime}, b^{\prime}\right)$ from country $h$;

$$
S_{j h}\left(a^{\prime}, b^{\prime}, a, b \psi\right)=\left[Z_{j h}\left(a^{\prime}, b^{\prime}, a, b\right)-I-V_{j}(a \psi)-V_{h}\left(a^{\prime}\right)\right](1-\beta) .
$$

The value of a firm that continues to operate independently is given in equation (5). Then any target firm, $(a, b)$, facing the realization of future productivity shocks, and the probability $\mu$ of meeting a potential acquirer, exhibits a flow value of

$$
\begin{aligned}
T_{j}(a, b)=\int_{\Psi}\left\{\frac{\mu}{J} \int_{1}^{J}\left[\int_{b_{L}}^{b_{H}} G_{a}\left(A_{j h}\right) S_{j h}\left(A_{j h}, b^{\prime}, a \psi, b\right) d G_{b}\left(b^{\prime}\right)\right]\right. \\
\left.+\left[(1-\mu)+\frac{\mu}{J} \int_{1}^{J} \int_{b_{L}}^{b_{H}}\left[1-G_{a}\left(A_{j h}\right)\right] d G_{b}\left(b^{\prime}\right)\right] V(a \psi, b)\right\} d F(\psi)
\end{aligned}
$$

The first term inside the braces is the value retained from a merger for the average potential acquirer, weighted by the likelihood of acquisition, while the second term is the value of continuing to operate independently, weighted by the likelihood of not being acquired, each evaluated for the realization of $\psi$. These values are then aggregated across the potential realizations of $\psi \in \Psi$ from the distribution $F(\psi) .{ }^{16}$

\subsection{Equilibrium Export Behavior}

In stage one, firms select which markets to serve in anticipation of shocks to their productivity, and the likelihood of acquisition. Forward looking firms do not simply choose to export to markets in which they currently earn non-negative profits. Recognizing the future impact of their export behavior on the likelihood of acquisition, firms trade off increases in their value as a target firm in (10), with the greater trade costs incurred when serving additional markets.

With our assumption that $f_{j j}=0$, firms will always operate domestically. However, since $f_{i j}>0$, firms may not serve all potential destinations, $i \in[1, J]$. A firm from country $j$ with initial

\footnotetext{
${ }^{16}$ Given that the productivity shocks, $\ln (1 / \psi)$ are log-normally distributed, the distribution function $F(\psi)$ can readily be obtained using method of transformations.
} 
productivity parameter $a$, will choose to serve country $i$ if, given future productivity shocks and the likelihood of acquisition, the net benefits of exporting are non-negative. Note that for the ordered set of export destinations $\mathcal{D}_{j}$, if a firm in country $j$ chooses to serve market $k$, then it also will export to all markets $i \in \mathcal{D}_{j}$ such that $c_{j}^{\epsilon} f_{i j} \tau_{i j}^{\epsilon-1} \leq c_{j}^{\epsilon} f_{k j} \tau_{k j}^{\epsilon-1}$. Thus, the export network of a firm $N_{j}(a, b)$ is fully characterized by the export destination that is the most costly for it to enter, which we denote $k_{j}(a, b)=\sup N_{j}(a, b)$. Optimal export decisions satisfy the following condition:

$$
\frac{d T_{j}(a, b)}{d k_{j}(a, b)}=b c_{j} f_{k_{j}(a, b) j},
$$

such that increasing the mass of export destinations of firm $a$ to include destination $k_{j}(a)$ equates the additional value earned by the target firm in (10) to the costs of entry into that market.

One of our key goals is to highlight the role of target firm exporting behavior in promoting cross-border M\&A activity. Equation (11) is useful in that it illustrates the relationship between target firm characteristics and their endogenous choice to establish export networks, which affects their value on M\&A markets. Firms with greater productivity earn higher profits in each market that they serve. Thus, the first implication of the condition in (11) is that firms with higher initial productivity within each country will export to more markets. The greater propensity of high productivity firms to export is now widely recognized; see for example Bernard \& Jensen (1999). ${ }^{17}$

Second, firms with lower export network costs, $b$, set up larger export networks, conditional on their productivity level $a$. While the role of firm-specific costs to set up networks is straightforward, it is important to note here because it will be useful in identifying the impact of export networks on cross-border M\&A activity as target firm productivities change over time. Furthermore, Bernard et al. (2003) provide evidence that, even after controlling for productivity, there is substantial heterogeneity in export activity among plants, and Roberts \& Tybout (1997) provide evidence that such heterogeneity in plant-level export behavior over time is consistent with the presence of sunk

\footnotetext{
${ }^{17} \mathrm{~A}$ key difference here is that firms may choose to export to particular markets even if future productivity shocks would make them potentially unprofitable to serve, given they retain the option of selling their export networks to high productivity acquirers. This forward looking export behavior, in which firms may serve some fringe markets at a loss in order to improve their valuation on acquisition markets, is distinct from the large literature on heterogeneous export behavior.
} 
costs to enter foreign markets.

A third implication of equation (11) is that firms with the same level of productivity and network setup costs, but from different countries, will establish different export networks because they face a different set of fixed costs, factor costs, and transport costs from their particular location. Thus, the location of country $j$ can independently grant an advantage in exporting to particular markets. For example, because of France's proximity to other European markets, French firms are likely to have an advantage relative to the U.S. in exporting to, say, Germany. The advantage that firms within some countries possess in establishing particular trade networks can make them attractive targets for cross-border M\&A, independent of firm-specific characteristics.

\section{Analysis of Cross-Border M\&A activity}

Purchasing a firm with a large export network, due to either greater initial productivity, lower setup costs, or locational advantages, allows a foreign acquirer to use the target's network as an export platform to countries that are otherwise unprofitable to serve. Several studies have suggested that global patterns of FDI are consistent with multinationals locating in countries that serve as effective export platforms to proximate markets, but ignored the role of cross-border M\&A, and the endogenous creation of export networks by target firms. ${ }^{18}$ Similarly, previous studies of crossborder M\&A activity have ignored export platforms as a potential motive. The following proposition demonstrates that target firms may appear to be "cherries" sought by multinationals on M\&A markets specifically because of their endogenous export behavior.

Proposition 1. Domestic firms that set up relatively large export networks are more likely to be acquired by a foreign multinational firm.

Proof. Note that firms endowed with greater values of $b$ set up smaller export networks, all else equal. Then, the result is evident from the following:

$$
\frac{d Y_{j h t}(a, b)}{d b}=\mu \frac{M_{h}}{M_{W}} \int_{b_{L}}^{b_{H}} g_{a}\left(A_{j h}\left(a, b, b^{\prime}\right)\right) d G_{b}\left(b^{\prime}\right) \frac{d A_{j h}\left(a, b, b^{\prime}\right)}{d b}<0
$$

\footnotetext{
${ }^{18}$ Examples of studies of export platform FDI and spatial FDI flows are Hanson et al. (2001), Yeaple (2003), Lai \& Zhu (2006), Blonigen et al. (2007) and Ekholm et al. (2007).
} 
where $\frac{d A_{j h}\left(a, b, b^{\prime}\right)}{d b}<0$ is the reduction in the mass of potential acquirers that generate a non-negative surplus by acquiring firms with higher network set up costs. A analagous result is obtained by considering export behavior that is due to differences in the initial levels of firm productivity.

The propensity of multinationals to acquire targets with highly valued export networks appears to contradict the conventional wisdom that acquirers seek under-performing "lemons" as potential targets. Here we argue that the seemingly opposing incentives to acquire high performing versus low performing targets are in reality differences in the effect of productivity across the states of firms' assets. In our multi-period framework we can investigate the impact of firm productivity changes, conditional on the initial investments in export networks, on the likelihood of acquisition.

Proposition 2. Firms that realize a persistent negative shock to their productivity level, after their export networks have been established, are more likely to be acquired relative to other targets.

Proof. Recall that an increase in the productivity parameter $a$ corresponds to a reduction in firm productivity. The result states that $\left.\frac{d Y_{j h t}(a, b)}{d a}\right|_{N_{j}(a, b)}>0$, where $N_{j}(a, b)$ is the export network established conditional on its initial productivity, which we hold fixed. Calculating from equation (9) directly we obtain

$$
\left.\frac{d Y_{j h t}(a, b)}{d a}\right|_{N_{j}(a, b)}=\left.\mu \frac{M_{h}}{M_{W}} \int_{b_{L}}^{b_{H}} g_{a}\left(A_{j h}\left(a, b, b^{\prime}\right)\right) d G_{b}\left(b^{\prime}\right) \frac{d A_{j h}\left(a, b, b^{\prime}\right)}{d a}\right|_{N_{j}(a, b)}>0
$$

where $\left.\frac{d A_{j h}\left(a, b, b^{\prime}\right)}{d a}\right|_{N_{j}(a, b)}>0$ is the increase in the mass of potential acquirers that generate a nonnegative surplus by acquiring firms that suffer negative productivity shocks, holding their initial investments in export networks fixed.

Propositions 1 and 2 indicate which types of firms are the preferred targets for multinational firms engaging in cross-border M\&A. Moreover, they predict when acquisitions are relatively more likely to take place during the life cycles of target firms. We refer to the behavior of acquirers seeking valuable assets, like export networks, and subsequently choosing to engage in M\&A activity after targets realize negative productivity shocks as multinationals acquiring "cherries for sale."

It is important to note that the incentives to acquire firms with large export networks, conditional on realizing a negative productivity shock, does not imply that firms with large export 
networks are relatively more likely to be acquired upon a loss in productivity; that is, a negative productivity shock does not magnify the propensity to acquire firms that export to many destinations. In an appendix we show that the joint effects of export activity and productivity changes on the likelihood of acquisition activity (i.e., $\frac{d^{2} Y_{j h t}(a, b)}{d a d b}$ holding initial investments in export activity constant) can generally be positive or negative. Although firms with both a large export network and negative productivity shock look relatively more desirable, there may also be relatively fewer potential acquirers who are profitable enough to make a successful takeover bid of a firm that had high enough productivity to set up large export networks in the first place. ${ }^{19}$

It is worth emphasizing that the result in Proposition 2 would differ if firms realized a negative shock before they established their export network. A firm that realizes a persistent productivity shock prior to investing in exporting activity would subsequently choose to enter fewer markets than the same firm would have prior to suffering a reduction in productivity. From the perspective of an acquirer, a firm with a small export network would not be an attractive target because there is less surplus generated from acquisition. Hence, shocks that precede investments in export activity would not promote cross-border M\&A, whereas shocks after sunk investments have been made do promote acquisition activity.

Thus far we have emphasized the endogenous export behavior of heterogeneous firms in motivating cross-border M\&A. The value of targets' export networks can also vary as exogenous geographical differences give rise to variation in trade costs across countries. The ability to serve markets from locations that result in lower trade costs also provides a motive for multinationals to engage in cross-border M\&A, and use the target firm's network as an export platform to proximate markets.

Proposition 3. Given the ordering of trade costs across export destinations for any host country, domestic targets are more likely to be acquired by foreign multinationals with higher trade costs across the same ordered set of export destinations, in terms of stochastic dominance.

\section{Proof. See Appendix}

\footnotetext{
${ }^{19}$ We show in an appendix that if the distribution of firm productivities is Pareto (which has been shown to be a good fit of firm size/productivity distributions in many countries) then the sign of $\frac{d^{2} Y_{\text {jht }}(a, b)}{d a d b}$ is positive, holding initial investments in export activity constant. We can also supply additional specifications from the empirical analysis that confirm the positive cross-partial effect upon request.
} 
All together, these results suggest distinct empirical strategies that examine target firm characteristics across time, and across the locations of potential acquirers, to identify the roles of export networks and productivity shocks in promoting cross-border M\&A activity.

\section{Empirical Strategy}

In this section we use the theory above to derive our empirical strategy for detecting the impacts of previous investments in export networks and recent productivity shocks on the likelihood of foreign acquisition of domestic firms. The outcome variable of interest is the probability that a domestic firm $d$ in sector $s$ is acquired by a foreign firm from location $h$ at time $t$, conditional on its initial productivity $a_{d, t-2}$, current productivity, $a_{d, t-1}$, and its specific costs to setup export networks, $b_{d}$, which we write $Y_{d s h t} \equiv \operatorname{Pr}\left(\right.$ Acquisition $\left._{d t} \mid a_{d, t-1}, a_{d, t-2}, b_{d}\right)$. Note that, given the annual frequency of observation, we indicate current firm-level characteristics as those observed in time period $t-1$, for a firm observed to be under new foreign ownership during time period $t$.

Specifying the current time period as $t-1$ avoids erroneously attributing firm characteristics that belong to an acquirer to be those of the target firm at any given time. Fich et al. (2011) provide evidence that the length of M\&A negotiations is approximately 120 days on average, and only 160 days at the upper quartile. Hence, allowing for a single year lag $t-1$ in target firm characteristics is likely to avoid the possibility that we are measuring changes in firm characteristics that are a result of acquisition activity. Guadalupe et al. (2012) adopt a similar practice when studying the consequences of acquisitions, and as we discuss below, we obtain qualitatively similar results if we use further lagged values in the baseline specification. Here we denote the initial time period as $t-2$ to ease exposition as we derive the empirical strategy. The model is easily generalized to a many period case, and all of our estimation results are robust to the inclusion of multiple time periods in the empirical model.

We specify the conditional probability as having a logistical distribution

$$
Y_{d s h t}=\Lambda\left(z_{d s h t}\right)+\xi_{d s h t} \equiv \frac{\exp \left(z_{d s h t}\right)}{1-\exp \left(z_{d s h t}\right)}+\xi_{d s h t}
$$

where we index the response probability to firm characteristics $\left(a_{d, t-2}, a_{d, t-1}, b_{d}\right)$, and other control 
variables $X_{d s h t}$, as

$$
z_{d s h t}=\beta_{0}-\beta_{1} \ln \left(a_{d, t-2}\right)-\beta_{2} \ln \left(a_{d, t-1}\right)+\beta_{3} b_{d}+X_{d s h t} \beta .
$$

Noting that $-\ln \left(a_{d, t}\right)$ is simply the observed $\ln T F P_{d, t}$ for firm $d$ at time $t$, given its productivity parameter $a$, we can rewrite the index function above as

$$
z_{d s h t}=\beta_{0}+\beta_{1} \ln T F P_{d, t-2}+\beta_{2} \ln T F P_{d, t-1}+\beta_{3} b_{d}+X_{d s h t} \beta .
$$

The firm-specific costs to enter foreign markets, $b_{d}$, are not observed. It may also be the case that the initial level of productivity for firm $d$ corresponds to a time period before the sample period begins. If the initial draws of productivity and export setup costs for each firm are unobserved and not independent, then obtaining unbiased estimates of the impact of prior levels of firm-level productivity in the model described by equations (12) and (13) is difficult, due to the well-known initial conditions problem. Arellano \& Carrasco (2003), Wooldridge (2005), and Honore \& Tamer (2006) discuss specifically the initial conditions problem in non-linear unobserved effects models, such as the logit specification in (12). The concern over estimated the role of unobserved firm-specific attributes is exacerbated in the context of prior investments in export capacity by the evidence in Roberts \& Tybout (1997) that there is significant variation in sunk costs across plants, and that sunk costs explain a large amount of variation in observed export activity across firms.

Even though the firm-specific parameters, $b_{d}$, are not observed, the theory above predicts that initial firm-level productivity and the firm-specific costs to enter markets impact the likelihood of acquisition through a target firm's choice to establish export networks. Specifically, the (log) number of export destinations, $\ln \operatorname{ExpNet}_{d t-2}$, established previously by targets can be written

$$
\ln \operatorname{ExpNet}_{d t-2}=\gamma_{0}+\gamma_{1} \ln T F P_{d t-2}+\gamma_{2} b_{d} .
$$

The optimal export behavior described in equation (11), as well as a large empirical literature, demonstrate that high productivity firms are more engaged in export activity and that sunk costs are significant in explaining variation in export activity across firms and time; see Bernard \& 
Jensen (1999), Bernard et al. (2003) and Roberts \& Tybout (1997). Thus we have $\gamma_{1}>0$, as more productive firms export to a greater number of destinations, and $\gamma_{2}<0$, as large setup costs deter target firms from exporting to foreign markets. To ease exposition we write equation (14) such that firms make sunk investments in a single time period prior to the current year, however (14) can generally be specified dynamically, so that it includes measures of previous levels of firm productivity. We will report the results of specifications that account for this possibility, and show that our results remain robust.

From an empirical point of view equation (14) is useful in that it provides an observable firm characteristic, export networks, that explicitly accounts for the conditional distribution of initial productivity and unobserved costs to enter each market for each firm. Then, solving (14) for $b_{d}$, and substituting into the index function in (13), we obtain

$$
\begin{aligned}
z_{d s h t}=\left(\beta_{0}-\frac{\beta_{3} \gamma_{0}}{\gamma_{2}}\right)+\left(\beta_{1}-\frac{\beta_{3} \gamma_{1}}{\gamma_{2}}\right) \ln T F P_{d, t-2}+\beta_{2} \ln T F P_{d, t-1} & \\
& +\frac{\beta_{3}}{\gamma_{2}} \ln \operatorname{ExpNet}_{d t-2}+X_{d s h t} \beta .
\end{aligned}
$$

It is also useful to note that firm-level productivities (in logs) evolve through time as a random walk. Our sample confirms that firm productivity evolves according to a random walk. The coefficient of a regression of the contemporaneous TFP on lagged TFP is 1.01. In accordance with the assumptions of the model we also find that log TFP evolves according to a random walk, with a coefficient of 0.98 when we regress $\operatorname{lnTFP}$ on it lagged value. Thus we can write

$$
\ln T F P_{d t-1}=\ln T F P_{d t-2}+\ln (1 / \psi)_{d t-1}
$$

where $\Delta \ln T F P_{d, t-1} \equiv \ln (1 / \psi)_{d t-1}$ is the firm-level shock to a target's productivity level, after it has invested in creating valuable assets such as export networks. Finally, we can substitute the relationship in equation (16), into the response probability in (15), and simplifying notation for 
parameters $(\beta$ and $\gamma)$ we obtain

$$
z_{d s h t}=\theta_{0}+\theta_{1} \operatorname{ExpNet}_{d, t-2}+\theta_{2} \Delta \ln T F P_{d, t-1}+\theta_{3} \ln T F P_{d, t-1}+X_{s d h t} \Theta
$$

Together the logit model in (12), and the derived index function in (17), characterize our empirical strategy.

The theory above predicts that previous investments in export networks, measured as $\operatorname{ExpNet}_{d, t-2}$, promote cross-border M\&A activity. Thus the predicted sign of $\theta_{1}$ is positive. Proposition 3 makes further predictions about the effect of export networks across sub-samples of acquiring countries. While locational differences and trade costs make export networks of domestic targets valuable to foreign acquirers, potential acquirers from the domestic country will already export to a similar set of markets. Redundancy in the export networks of domestic targets should make them relatively less valuable to domestic acquirers. To evaluate this prediction we estimate a multinomial logit model for the likelihood of foreign versus domestic acquisition, relative to the excluded group of firms that are not acquired. Proposition 3 predicts that in the multinomial logit regression, the marginal effect of export networks is positive for foreign acquirers, and equal to zero for domestic acquirers. To further evaluate the role of export networks across the locations of acquirers, we estimate the logit model separately for the sub-sample of foreign acquisitions from nearby countries (European nations) and the sub-sample of acquisitions from far-away countries (Non-European nations). The prediction is that non-European countries will value the export networks established by French targets more that acquirers from nearby countries. ${ }^{20}$

Investments in export networks cause domestic firms to appear as high value cherries to foreign acquirers, making them more likely targets for takeover. Our model also makes predictions as to when target firms that invest in export capacity are more likely to be acquired. Proposition 2 predicts that reductions in firm-level productivity after investments in establishing export networks,

\footnotetext{
${ }^{20}$ As we discuss in detail below, because we estimate the relative likelihood of acquisition using a non-linear multinomial logit model, the prediction that the marginal impact of export networks on the likelihood of acquisition by non-European firms is larger than for European firms does not require that $\theta_{1}^{E U R}<\theta_{1}^{N o n-E U R}$. Instead we will focus on the relative magnitudes of the marginal effects for each group. We then compare the marginal effects evaluated at the respective sample means of observed export networks.
} 
$\Delta \ln T F P_{d, t-1}$, increase the likelihood of acquisition. A negative sign for $\theta_{2}$ indicates propensity to seek targets who are currently "for sale" on domestic M\&A markets. The specification of our empirical model incorporating lagged firm characteristics allows us to simultaneously estimate the impact of previous investments in valuable assets such as export networks and the impact of reductions in firm productivity over time. Estimates such that $\theta_{1}>0$ and $\theta_{2}<0$ indicate that cross-border M\&A activity is characterized by multinationals seeking "cherries for sale."

Our theory makes no prediction about how the current level of TFP of a target firm impacts the likelihood of acquisition once we condition on previous productivity shocks and established export networks of a target firm; with productivities evolving according to a random walk, the shock to firm productivity, $\Delta \ln T F P_{d, t-1}$, is sufficient to characterize how the outside option of producing independently with its own productivity level, $\ln T F P_{d, t-1}$, has changed for each target firm. Yet, our model only considers the ex ante role of firm productivity in promoting investments in assets such as export networks. Guadalupe et al. (2012) show that the current TFP level of a domestic target firm is positively associated with the likelihood of foreign acquisition, because of ex post investments in technologies made by the acquirer. They argue that these investments are complementary to the current productivity of a target firm. In line with their findings we expect to find that $\theta_{3}>0$.

The vector $X_{d s h t}$ contains several additional control variables that might promote cross-border M\&A activity independently. Heyman et al. (2007) show that foreign acquirers seek targets with relatively high skill workers, suggesting that integration of the acquiring firm technology may be a skill-bias activity. We include controls for the skill intensity of the workforce of target firms, and accordingly expect that a more skill intensive workforce will increase the likelihood of foreign takeover. Firms may possess other intangible assets that make them attractive as targets as well. For example, Blonigen \& Taylor (2000) argue that firms can use M\&A to substitute for costly research and development. Lee (2011) argues that cross-border M\&A is motivated by firms seeking specific technologies, and Nocke \& Yeaple (2008) highlight the incentives for takeover of firms which possess strong market potential. We include a set of intangible assets, such as R\&D expenditure and goodwill, to account for these distinct motivations for foreign acquisition. Finally, Desai et al. 
(2004) demonstrate that multinational firms have access to internal credit markets across countries that may alleviate financial conditions among affiliate firms. This presence of credit constraints among target firms which could independently motivate acquisition by a multinational firm. We include a measure of credit constraints faced by French firms, Payment Incidents, to account for this alternative incentive to engage in cross-border M\&A.

We also include time specific effects, $\tau_{t}$, which capture aggregate macroeconomic conditions of the economy that may affect M\&A activity. For example, the timing of acquisitions typically ebbs and flows in merger waves, even if motivated by economic fundamentals; see Harford (2005). We include sector-specific effects for each 4-digit sector level. A sector fixed effects strategy accounts for fixed differences in cross-border M\&A activity, as well as fixed differences in export activity within the host country across sectors.

Although the lagged values of export networks will account for firm specific costs to enter foreign markets, including firm-specific effects still may be useful. We have specified the evolution of firm-level productivity as a random walk, where each firm realizes shocks drawn from the same distribution. In practice, firms may draw productivity shocks from distributions with different amounts of drift, leading to differences in the propensity of firms to accept similar takeover bids, independent of their specific attributes $a$ and $b$. Thus we will also report estimates from specifications that include firm-fixed effects. ${ }^{21}$

\section{Data}

While section 2 above described some of the primary data we have and how we construct our measures of TFP and export networks, we next describe the additional data that we employ in our econometric analysis. These additional data provide the important control variables (mentioned above) that may also affect cross-border M\&A activity and which we want to include in order to avoid spurious inferences.

Data regarding workers and occupations come from the "DADS Panel"-Declaration Annuelle

\footnotetext{
${ }^{21}$ Without firm-level fixed effects, the appropriate counter-factual is the observed export networks and changes in TFP for acquired firms, relative to non-acquired firms. In specifications that include firm fixed effects we exclude non-acquired firms and examine differences target firm characteristics before and after the time of acquisition.
} 
Table 1: Summary Statistics

\begin{tabular}{|c|c|c|c|c|c|c|}
\hline & Obs. & Mean & Std.Dev. & Obs. & Mean & Std.Dev \\
\hline & \multicolumn{3}{|c|}{ Whole Sample } & \multicolumn{3}{|c|}{ Acquired Foreign Affiliates } \\
\hline Foreign Affiliate [1/0] & 32883 & 0.092 & 0.289 & 2728 & 0.470 & 0.499 \\
\hline $\ln (\text { Export Network })_{t_{-2}}$ & 32883 & 1.798 & 1.224 & 2728 & 2.338 & 1.117 \\
\hline$\Delta \ln (\mathrm{TFP})_{t_{-1}}$ & 32883 & 0.030 & 0.231 & 2728 & 0.040 & 0.236 \\
\hline$\Delta \ln (\mathrm{TFP})_{t_{-2}}$ & 25363 & 0.037 & 0.230 & 2213 & 0.049 & 0.246 \\
\hline $\ln (\mathrm{TFP})_{t_{-1}}$ & 32883 & 3.940 & 1.042 & 2728 & 4.508 & 1.099 \\
\hline Share of Intangible $t_{-1}$ & 32883 & 0.109 & 0.160 & 2632 & 0.136 & 0.193 \\
\hline Skill Intensity $_{t_{-1}}$ & 32883 & 0.306 & 0.190 & 2679 & 0.369 & 0.207 \\
\hline Payment Incidents $_{t_{-1}}$ & 32883 & 0.029 & 1.073 & 2728 & 0.245 & 3.182 \\
\hline Ile de France & 32883 & 0.196 & 0.394 & 2728 & 0.250 & 0.433 \\
\hline
\end{tabular}

de Données Sociales, an employer-employee dataset collected by the INSEE (Institut National de la Statistique et des Etudes Economiques). ${ }^{22}$ The DADS report mandatory information on all declared employees including the number of yearly hours worked, wages and occupation. The French classification of occupations identifies skilled and unskilled workers. Skill groups correspond to the 2-digit French Classification of Occupations and Social Categories. We divide these categories into two groups: skilled non-production workers (executives, technicians, administrative occupations, clerks) and production workers. We compute the skill intensity at firm-level as the share of hours worked by skilled non-production workers in the total number of hours worked. Information on the value of intangible and tangible assets are taken from the BRN (Bénéfice Réel Normal ordinary actual profit), a mandatory tax form for any firm with revenue larger than 763,000 euros in manufacturing. The share of intangible assets is simply the ratio of intangible assets to total assets.

We identify financially constrained firms by exploiting a database derived from regulatory constraints in the French banking system. Since 1992, banks are legally obligated to report any incident

\footnotetext{
${ }^{22}$ This data is a yearly notification of social data filled by any firm with employees. Information on age, gender, experience, occupation, sector, region, firm identifier, plant size, compensation.
} 
of a firm failing to pay its creditors within four business days. These defaults on credits are called Payment Incidents. Banks use this information to adapt their supply of credit to firms, so that observed payment incidents are informative about the potential access to credit for French target firms. ${ }^{23}$ The Banque de France collects this information and makes 12-month histories available freely to all commercial banks and other credit institutions. We make use of the historical series, and compute the total value of incidents, within a year, for each firm since 2000. The matching with our data is permitted by the use of a common administrative ID for the firm. A full description of the sample construction is provided in the Appendix.

Table 1 provides simple summary statistics for each variable used in estimation for the sample of all foreign affiliates, as well as the sample of targets which we observed being newly acquired by foreign multinationals. We will employ two samples. The first is a sample that is composed of domestic firms that have become foreign owned during the sample period, as well as French firms that did not change their ownership over 1999-2006. We accordingly drop all observations for (i) firms acquired by French firms after becoming foreign owned, (ii) independent firms acquired by French groups, (iii) firms that have always been foreign owned from 1999-2006, and (iv) French groups acquired by French groups. The corresponding sample is composed of 32,883 observations. Descriptive statistics for our variables with this sample are in the left columns of Table 1. When we introduce fixed effects in a logit estimation, we reduce the sample to only those French firms that were acquired by a foreign firms at some point in our sample. This reduces our sample size to 2,728 observations and descriptive statistics for this sample are reported in the right columns of Table $1 .^{24}$

\footnotetext{
${ }^{23}$ There are several reasons we would observe payment incidents, ranging from a material error to an actual default of payment. We select cases corresponding to insufficient liquidity of the debtor and drop cases related to material error or contested claims. These data have been used in several previous studies to identify financial constraints among firms. See for example Aghion et al. (2012) and Bricongne et al. (2012).

${ }^{24}$ In the appendix, we show comparisons of TFP levels, employment and trade volumes between foreign-owned and domestic firms. In line with previous studies foreign-owned firms (unconditionally) exhibit higher productivity, employ more workers, pay higher wages, and trade more than their domestic counterparts.
} 


\section{Results}

The section is divided into five parts corresponding to our different empirical strategies: (i) we focus on the export networks and productivity changes at acquired targets relative to firms that are never acquired; (ii) we incorporate firm-level fixed effects into the empirical model and analyze export networks and productivity shocks within acquired targets prior to their acquisition; (iii) we reconsider alternative specifications of export networks that also account for the number of products exported by each target; (iv) we compare firm characteristics across those that are targets for domestic versus multinational acquirers; and (v) we provide evidence that the role of export networks varies across the acquiring firm's country of origin, as predicted by the model.

\subsection{Evidence Comparing Targets to Non-Acquired Firms}

The estimation results from the sector fixed effects logistic regression are given in Table 2 . The reported values correspond to the marginal effects evaluated at sample means. All specifications include 4-digit sector fixed effects and year effects.

Looking across each specification in Table 4 we find strong evidence that previously established export networks provide significant motivation for cross-border M\&A activity. In column (1) we include only the export characteristics of a firm, defined as the number of countries to which a firm exports. In columns (4)-(6), we introduce other firm level characteristics that may independently motivate foreign acquisition. Even after controlling for these other firm-level characteristics the established trade networks have a significant impact on the likelihood of acquisition.

The effect of the export characteristics of target firms is quantitatively significant as well. Based on the preferred estimates from columns (5) and (6) that include a full set of controls, a standard deviation increase in a firm's export network (about a 66\% increase) raises its likelihood of being acquired by 0.54 percentage points. With an average probability of foreign acquisition of $1.5 \%$ in each year, an export network that is a standard deviation above the mean implies approximately a roughly a $33 \%$ greater likelihood in the probability of foreign acquisition. In other words, the pseudo-elasticity between changes in export networks and the likelihood of acquisition is near 0.5. Another way to consider the quantitative impact of export networks is to note that the average

number of markets served among French firms is approximately 12. Thus, exporting to even a 
Table 2: Results: Logistic Estimation with Sector Fixed Effects

\begin{tabular}{|c|c|c|c|c|c|c|}
\hline & $(1)$ & (2) & (3) & (4) & $(5)$ & (6) \\
\hline $\ln (\text { ExportNetwork })_{t_{-2}}$ & $\begin{array}{l}0.028 * * * \\
(0.002)\end{array}$ & & & $\begin{array}{l}0.011 * * * \\
(0.002)\end{array}$ & $\begin{array}{l}0.008 * * * \\
(0.002)\end{array}$ & $\begin{array}{l}0.008 * * * \\
(0.003)\end{array}$ \\
\hline$\Delta \ln (\mathrm{TFP})_{t_{-1}}$ & & $\begin{array}{l}-0.001 \\
(0.005)\end{array}$ & $\begin{array}{l}-0.018 * * * \\
(0.005)\end{array}$ & $\begin{array}{l}-0.014 * * * \\
(0.005)\end{array}$ & $\begin{array}{l}-0.014 * * * \\
(0.005)\end{array}$ & $\begin{array}{l}-0.013^{*} \\
(0.007)\end{array}$ \\
\hline $\ln (\mathrm{TFP})_{t_{-1}}$ & & & $\begin{array}{l}0.039 * * * \\
(0.003)\end{array}$ & $\begin{array}{l}0.032 * * * \\
(0.003)\end{array}$ & $\begin{array}{l}0.033 * * * \\
(0.003)\end{array}$ & $\begin{array}{l}0.037 * * * \\
(0.003)\end{array}$ \\
\hline Share of Intangible $t_{t-1}$ & & & & & $\begin{array}{l}0.025^{*} \\
(0.013)\end{array}$ & $\begin{array}{l}0.032 * \\
(0.016)\end{array}$ \\
\hline Share of Skill $t_{-1}$ & & & & & $\begin{array}{l}0.107 * * * \\
(0.015)\end{array}$ & $\begin{array}{l}0.118 * * * \\
(0.018)\end{array}$ \\
\hline Payment Incidents $_{t_{-1}}$ & & & & & $\begin{array}{l}0.003^{*} \\
(0.002)\end{array}$ & $\begin{array}{l}0.006 \\
(0.005)\end{array}$ \\
\hline Ile de France & & & & & $\begin{array}{l}-0.017 * * * \\
(0.006)\end{array}$ & $\begin{array}{l}-0.017 * * \\
(0.008)\end{array}$ \\
\hline$\Delta \ln (\mathrm{TFP})_{t_{-2}}$ & & & & & & $\begin{array}{l}-0.004 \\
(0.006)\end{array}$ \\
\hline Sector FE & yes & yes & yes & yes & yes & yes \\
\hline Year Effects & yes & yes & yes & yes & yes & yes \\
\hline Observations & 32,883 & 32,883 & 32,883 & 32,883 & 32,883 & 25,063 \\
\hline Pseudo $R^{2}$ & 0.133 & 0.104 & 0.158 & 0.162 & 0.175 & 0.175 \\
\hline
\end{tabular}


single additional market is roughly equivalent to a $10 \%$ larger export network, corresponding to a $5 \%$ increase in the likelihood of acquisition.

It is worth noting that the positive effect of export networks is maintained even when we introduce measures of firm TFP levels. The well-known stylized fact is that high-productivity firms invest in exporting capacity more than those with lower productivity, as they are better able to cover fixed exporting costs. ${ }^{25}$ However, the fact that we find a positive and robust impact of previous exporting behavior after controlling for TFP levels is consistent with our assertion in the theory above that investments in export capacity are, at least in part, sunk costs. Targets are more attractive for having established export networks, even after controlling for differences in their ability to do so in the future.

The second hypothesis from the model is that negative productivity shocks increase the surplus generated by a merger, further motivating cross-border M\&A. In column (2) we include only the measured change in productivity experienced in the previous year. As expected, without controlling for potentially valuable assets held by the target, productivity shocks have no estimated impact on the likelihood of foreign acquisition. Proposition 2 states that negative shocks promote cross-border M\&A when other firm characteristics are held fixed. Once we account for other firmlevel characteristics we obtain a strong and robust negative impact of productivity shocks on the probability of being acquired by a foreign multinational.

The negative coefficient on the lagged changes in productivity in columns (4)-(6) suggest that a productivity shock that is $10 \%$ above average corresponds to 0.13 percentage point increase, or equivalently about a $8.6 \%$ increase, in the probability of foreign acquisition. We observe large differences in productivity shocks across firms in our sample; See Table (1). Thus, the estimated pseudo-elasticity of 0.86 suggests substantial differences in the likelihood of foreign acquisition for firms that receive various shocks to their productivity in each year.

One may be concerned that additional lags in productivity, or more specifically previous shocks to firm-level TFP, may also promote takeover in the current period. Our empirical model described in equations (12) and (17) can easily be generalized to accommodate further lags in firm charac-

\footnotetext{
${ }^{25}$ See for example Bernard \& Jensen (1999).
} 
teristics. With productivity evolving according to a random walk, this is equivalent to including additional lagged values of TFP shocks. In column (6) we introduce an additional measure of previous shocks, $\Delta \ln T F P_{t_{-2}}$, and find that it has no effect. Predetermined export activity and the latest shock to target-firm productivity appear to be sufficient in describing the changes within target firms that promote cross-border M\&A activity.

In the theory we have assumed that all shocks to firm productivity are persistent. Indeed our sample of French firms provides strong evidence that productivity evolves according to a random walk. However, it may be possible that some shocks are only temporary. We have estimated each specification in Table 2, where shocks that are relatively small (less than a half of a standard deviation) are normalized to zero, as these small shocks may be more likely to be viewed as temporary by potential acquirers. We find identical quantitative results when only large shocks are considered. Complementary results to Table 2, using instead labor productivity, also yield identical qualitative results and are available from the authors upon request.

All of the estimated effects of other firm-level characteristics are in line with previous findings. Firms with a relatively more skill-intensive workforce are more likely to be acquired, as are those with a substantial share of intangible assets. The positive coefficient on TFP levels is consistent with the previous evidence from many other countries, including Chile, Indonesia, the U.S., and Spain. The regression results which account other firm characteristics confirm the patterns illustrated in Figure 1; none of the regression results in Table 2 are affected by the inclusion of additional firm-level controls.

A final concern about the estimated effects in Table 2 may be that there is reverse causality such that targets strategically lower their productivity in anticipation of a future merger. Yet, Fich et al. (2011) reports evidence from administrative filings that, even at the upper quartile, the length of M\&A negotiations, from the time of first contact to completion, is approximately 160 days or less. The one year lag on productivity levels and shock is likely to be immune to bias from reverse causality if managers were to alter target firm characteristics in anticipation of a merger. Moreover, there is little reason to think that managers may strategically manipulate their balance sheets in a way that would lower their TFP, even if it promotes takeover. Targets that suffer productivity 
shocks are more likely to be acquired because a greater share of potential acquirers that can make a successful takeover bid. Lower productivity does not improve the strike price of acquisitions, nor the option of operating independently if a potential acquisition fails. As seen in equation (10), a target firm's valuation is increasing in its productivity. And in practice, executives are compensated by equity stakes and stock options that are more valuable when strike prices are high; see Fich et al. (2011) and Heitzman (2011). The incentives of managers to strategically increase productivity, and therefore the raise strike prices of acquisitions, only works against our results in Table 2. Finally, to further assuage concerns about reverse causality or anticipation of acquisition contaminating our estimates we have also run the model with additional lags. Specifying the model estimated in Table 2 with additional lags, which considers productivity shocks two full years prior to acquisition and export networks established three years prior to acquisitions, yields identical qualitative results.

\subsection{Evidence Looking Within Acquired Targets}

In this section, we incorporate firm-level fixed effects to estimate the impact of target firm characteristics on the probability of switching from French to foreign ownership status. There are two reasons that we wish to estimate (12) with firm-level fixed effects. First, one may be concerned that the positive effect reported in the previous section for established export networks is actually due to the formation of other unobserved assets that are correlated with investments in export activity. Incorporating firm fixed effects accounts for any independent, but unobserved, M\&A determinants that are specific to the firm and time invariant. Second, looking within acquired firms we are able to identify the distinct effects of export networks and productivity shocks, consistent with acquisition activity where multinationals seek cherries for sale. It is possible that the previous results from the sector-fixed effects specification are due to two distinct groups of acquired firms: those with negative productivity shocks and those with large export networks. ${ }^{26}$ The sample reduces to 512 acquired targets and 2,728 observations over the sample period. Again, the treatment group in the sample is the set of firms acquired by foreign multinationals, but the control group for this empirical strategy is composed of French firms before the year of acquisition.

\footnotetext{
${ }^{26}$ Of course Figure 1 allays such concerns, since the entire distribution of acquired targets, from the 5th-95th percentile in productivity, suffer losses prior to acquisition, in addition to having a larger than average export network.
} 
Table 3: Logistic Estimation with Firm Fixed Effects

\begin{tabular}{|c|c|c|c|c|c|}
\hline & (1) & $(2)$ & (3) & (4) & (5) \\
\hline $\ln (\text { ExportNetwork })_{t_{-2}}$ & $\begin{array}{l}1.097 * * * \\
(0.193)\end{array}$ & & $\begin{array}{l}1.080 * * * \\
(0.193)\end{array}$ & $\begin{array}{l}0.936 * * * \\
(0.230)\end{array}$ & $\begin{array}{l}0.732 * * * \\
(0.267)\end{array}$ \\
\hline$\Delta \ln (\mathrm{TFP})_{t_{-1}}$ & & $\begin{array}{l}-0.581 * * * \\
(0.193)\end{array}$ & $\begin{array}{l}-0.526^{* * *} \\
(0.195)\end{array}$ & $\begin{array}{l}-2.145^{* * *} \\
(0.328)\end{array}$ & $\begin{array}{l}-3.488 * * * \\
(0.684)\end{array}$ \\
\hline $\ln (\mathrm{TFP})_{t_{-1}}$ & & & & $\begin{array}{l}3.916 * * * \\
(0.595)\end{array}$ & $\begin{array}{l}5.560 * * * \\
(1.015)\end{array}$ \\
\hline Share of Intangible $t_{-1}$ & & & & $\begin{array}{l}4.764 * * * \\
(1.537)\end{array}$ & $\begin{array}{l}5.882 * * \\
(2.348)\end{array}$ \\
\hline Share of Skill $t_{-1}$ & & & & $\begin{array}{l}13.247 * * * \\
(1.967)\end{array}$ & $\begin{array}{l}10.377 * * * \\
(2.358)\end{array}$ \\
\hline Payment Incidents $t_{t_{-1}}$ & & & & $\begin{array}{l}-0.019 \\
(0.020)\end{array}$ & $\begin{array}{l}-0.026 \\
(0.054)\end{array}$ \\
\hline Ile de France & & & & $\begin{array}{l}-2.735 * * * \\
(0.929)\end{array}$ & $\begin{array}{l}-15.184 * * * \\
(0.732)\end{array}$ \\
\hline$\Delta \ln (\mathrm{TFP})_{t_{-2}}$ & & & & & $\begin{array}{l}-2.288 * * * \\
(0.503)\end{array}$ \\
\hline Firm FE & yes & yes & yes & yes & yes \\
\hline Year Effects & yes & yes & yes & yes & yes \\
\hline Observations & 2,728 & 2,728 & 2,728 & 2,601 & 1,587 \\
\hline Pseudo $R^{2}$ & 0.029 & 0.006 & 0.033 & 0.218 & 0.201 \\
\hline No. of Switchers & 512 & 512 & 512 & 498 & 352 \\
\hline
\end{tabular}

Robust standard errors clustered at firm-level in parentheses.

$* * *, * *, *$ significantly different from 0 at $1 \%, 5 \%$ and $10 \%$ level, respectively.

Table 3 provides additional support for the positive impact of previously established export networks, and the effects of negative productivity shocks, in promoting cross-border M\&A activity. The inclusion of firm-level fixed effects precludes calculations of marginal effects, but looking within acquired targets the coefficient on the number of previously established export destinations continues to be positive and significant, consistent with the positive marginal effect reported in Table $2 .{ }^{27}$ In Table 3 we also continue to find that negative productivity shocks encourage takeover.

\footnotetext{
${ }^{27}$ In Table 3 we continue to report estimates from specifications that use export networks observed two years prior to acquisition, as in Table 2. However we find nearly identical results if we use earlier observations $(t-3$ or $t-4)$ from each acquired target. Recall that Figure 1 shows that the export networks among target firms grow following acquisition, and Guadalupe et al. (2012) find that foreign multinationals make significant investments in export capacity following takeover of Spanish firms. Note that this formation of new nodes on the export network of acquired firms only works
} 
Now that we examine productivity changes within individual acquired firms, we find that further lags in changes to TFP may also contribute to the probability of acquisition by foreign firms (see column (5)), however with firm-level fixed effects we cannot discern whether the additional lag has significant marginal impact on the likelihood of acquisition. ${ }^{28}$

\subsection{Alternative Specifications}

So far we have presented evidence that the number of countries to which a target firm exports will positively affect its likelihood of acquisition by a foreign multinational. This specification of export networks is consistent with the evidence in Arkolakis \& Muendler $(2011,2013)$ that exporting activity is strongly fragmented across national markets. On the other hand, Bernard et al. (2011) argue that firms may make different export decisions for different products in their portfolio if there are product specific costs to establish export networks. The theory above also predicts that the additional product line manufactured by target firms may contribute to the surplus generated by a merger, and hence alter the likelihood of foreign acquisition. In this section we examine the cherry effect of established export networks on cross-border M\&A activity, looking across the number of export destinations, number of products exported, and number of productdestination pairs.

Table 4 provides evidence that export networks, defined as product-destination pairs, promote foreign acquisition. Columns (1)-(2) report estimated marginal effects from specifications that include 4-digit sector fixed effects. Columns (3)-(4) report the coefficient estimates from specifications that include firm-level fixed effects. In columns (5)-(6) we decompose the product-destination pairs and include the number of countries that a target exports to, and the number of products exported, independently. The estimates in columns (1)-(4), which define export network as the number of country-product pairs, are consistent with the predicted cherry effects of export behavior on the likelihood of foreign acquisition: larger export networks promote foreign acquisition. However, in columns (5) and (6) we find that the number of countries to which a target exports is the key feature of its export behavior that attracts foreign acquirers. After controlling for the

against finding a positive effect of previous export behavior on the likelihood of foreign acquisition.

${ }^{28}$ In column (5) the number of observations drops due to the introduction of additional lagged variables. 
Table 4: Alternative Specifications of Export Networks

\begin{tabular}{|c|c|c|c|c|c|c|}
\hline & $(1)$ & $(2)$ & (3) & (4) & $(5)$ & (6) \\
\hline $\begin{array}{l}\ln (\text { Export } \\
\quad \text { Network) }{ }_{i t_{-2}}^{C P}\end{array}$ & $\begin{array}{l}0.004 * * \\
(0.002)\end{array}$ & $\begin{array}{l}0.004 * \\
(0.002)\end{array}$ & $\begin{array}{l}0.619 * * * \\
(0.166)\end{array}$ & $\begin{array}{l}0.362 * \\
(0.198)\end{array}$ & & \\
\hline $\begin{array}{l}\ln (\text { Export } \\
\text { Network) })_{i t_{-2}}^{C}\end{array}$ & & & & & $\begin{array}{l}0.011 * * * \\
(0.004)\end{array}$ & $\begin{array}{l}0.834 * * * \\
(0.292)\end{array}$ \\
\hline $\begin{array}{l}\ln (\text { Export } \\
\quad \text { Network })_{i t_{-2}}^{P}\end{array}$ & & & & & $\begin{array}{l}-0.004 \\
(0.004)\end{array}$ & $\begin{array}{l}-0.225 \\
(0.209)\end{array}$ \\
\hline$\Delta \ln (\mathrm{TFP})_{i t_{-1}}$ & $\begin{array}{l}-0.014 * * * \\
(0.005)\end{array}$ & $\begin{array}{l}-0.014 * * \\
(0.007)\end{array}$ & $\begin{array}{l}-2.154 * * * \\
(0.326)\end{array}$ & $\begin{array}{l}-3.545^{* * *} \\
(0.675)\end{array}$ & $\begin{array}{l}-0.014 * * \\
(0.007)\end{array}$ & $\begin{array}{l}-3.501 * * * \\
(0.683)\end{array}$ \\
\hline$\Delta \ln (\mathrm{TFP})_{i t_{-2}}$ & & $\begin{array}{l}-0.004 \\
(0.006)\end{array}$ & & $\begin{array}{l}-2.336 * * * \\
(0.493)\end{array}$ & $\begin{array}{l}-0.004 \\
(0.006)\end{array}$ & $\begin{array}{l}-2.321 * * * \\
(0.502)\end{array}$ \\
\hline $\ln (\mathrm{TFP})_{t_{-1}}$ & $\begin{array}{l}0.034 * * * \\
(0.003)\end{array}$ & $\begin{array}{l}0.038^{* * *} \\
(0.004)\end{array}$ & $\begin{array}{l}3.966 * * * \\
(0.591)\end{array}$ & $\begin{array}{l}5.657 * * * \\
(0.995)\end{array}$ & $\begin{array}{l}0.038 * * * \\
(0.004)\end{array}$ & $\begin{array}{l}5.589 * * * \\
(1.009)\end{array}$ \\
\hline $\begin{array}{l}\text { Share of } \\
\text { Intangible }_{t_{-1}}\end{array}$ & $\begin{array}{l}0.026 * * \\
(0.013)\end{array}$ & $\begin{array}{l}0.033 * * \\
(0.016)\end{array}$ & $\begin{array}{l}4.907 * * * \\
(1.524)\end{array}$ & $\begin{array}{l}6.015^{* *} \\
(2.362)\end{array}$ & $\begin{array}{l}0.032 * * \\
(0.016)\end{array}$ & $\begin{array}{l}5.963 * * \\
(2.363)\end{array}$ \\
\hline $\begin{array}{l}\text { Share of } \\
\text { Skill }_{t_{-1}}\end{array}$ & $\begin{array}{l}0.110 * * * \\
(0.015)\end{array}$ & $\begin{array}{l}0.120 * * * \\
(0.018)\end{array}$ & $\begin{array}{l}13.186^{* * * *} \\
(1.945)\end{array}$ & $\begin{array}{l}10.276^{* * * *} \\
(2.299)\end{array}$ & $\begin{array}{l}0.119 * * * \\
(0.018)\end{array}$ & $\begin{array}{l}10.272 * * * \\
(2.316)\end{array}$ \\
\hline $\begin{array}{l}\text { Payment } \\
\text { Incidents }_{t_{-1}}\end{array}$ & $\begin{array}{l}0.003^{*} \\
(0.002)\end{array}$ & $\begin{array}{l}0.007 \\
(0.005)\end{array}$ & $\begin{array}{l}-0.021 \\
(0.020)\end{array}$ & $\begin{array}{l}-0.027 \\
(0.052)\end{array}$ & $\begin{array}{l}0.007 \\
(0.005)\end{array}$ & $\begin{array}{l}-0.024 \\
(0.050)\end{array}$ \\
\hline Ile de France & $\begin{array}{l}-0.017 * * \\
(0.006)\end{array}$ & $\begin{array}{l}-0.017 * * \\
(0.008)\end{array}$ & $\begin{array}{l}-2.799 * * * \\
(0.927)\end{array}$ & $\begin{array}{l}-14.03 * * * \\
(0.706)\end{array}$ & $\begin{array}{l}-0.017 * * \\
(0.008)\end{array}$ & $\begin{array}{l}-15.25^{* * *} \\
(0.707)\end{array}$ \\
\hline Sector FE & yes & yes & no & no & yes & no \\
\hline Firm FE & no & no & yes & yes & no & yes \\
\hline Year Effects & yes & yes & yes & yes & yes & yes \\
\hline Observations & 32,883 & 25,063 & 2,601 & 1,587 & 25,063 & 1,587 \\
\hline Pseudo $R^{2}$ & 0.174 & 0.174 & 0.213 & 0.194 & 0.175 & 0.200 \\
\hline No. Switchers & . & . & 498 & 352 & . & 352 \\
\hline
\end{tabular}


number destination markets, the number of products exported by a target has no significant impact on the likelihood of acquisition. Consistent with the model above, investments made in the ability to serve foreign markets attracts multinational acquirers.

The regression models estimated in Table 4 generate similar goodness-of-fit regardless of how the export networks are specified; note that the pseudo- $R^{2}$ is nearly the same across definitions of export networks in Tables 2 and 3. As a basis of comparison note that the specification in column (2) of Table 4 is equivalent to the specification in column (6) of Table 2 for the corresponding definitions of export networks. The marginal effect of a larger export network defined as productdestination pair is nearly half the estimated effect of an increase in the number of foreign markets served; i.e., the elasticity with respect to the the number of product-destination pairs is approximately 0.4 versus an elasticity of the probability of foreign acquisition with respect to the number of export destinations estimated to be 0.8 . The fact that both the statistical and economic impacts of the number of products exported are small further confirms that the number of countries to which a firm exports is the key aspect of its export behavior on the M\&A market. From this point forward we will continue to define a target's export network according the number of export destinations.

In Figure 1, and in each of the preceding empirical specifications, we measure productivity shocks among target firms using estimated firm-level TFP that is obtained from the well-known procedure offered in Olley \& Pakes (1996). As an alternative to this structural approach to measure firm-level performance, in Table 5 we consider observed firm-level market shares. Specifically, we calculate the total revenue for each target firm earned in the domestic (French) market divided by the total domestic revenue of all firms in the same 4-digit sector. Column (1) of Table 5 presents the results of our preferred specification including sector fixed effects (corresponding to the results with firm-level TFP in Table 2), while Column (2) presents the results of our preferred specification including firm-level fixed effects (corresponding to the results in Table 3).

In both specifications that use firm-level market share as an alternative to TFP, we continue to find results consistent with the cherries for sale behavior in cross-border M\&A activity. The positive marginal effect on the export network variable, which is significant at the one percent level, indicates that acquirers indeed seek a targets that serve multiple foreign markets. Moreover, 
Table 5: Market Share as Alternative Measure of Firm Performance

\begin{tabular}{lll}
\hline & $\begin{array}{l}\text { Logit } \\
(1)\end{array}$ & $\begin{array}{l}\text { Logit FE } \\
(2)\end{array}$ \\
\hline $\ln (\text { ExportNetwork })_{t-2}$ & $\begin{array}{l}0.008^{* * * *} \\
(0.002)\end{array}$ & $\begin{array}{l}0.726^{* * *} \\
(0.210)\end{array}$ \\
$\Delta \ln (\text { MarketShare })_{t-1}$ & $-0.007^{* * *}$ & $-0.281^{* *}$ \\
& $(0.001)$ & $(0.138)$ \\
$\ln (\text { MarketShare })_{t_{-1}}$ & $0.016^{* * *}$ & $0.635^{* * *}$ \\
& $(0.002)$ & $(0.222)$ \\
Share of Intangible $t_{-1}$ & 0.014 & $3.843^{* * *}$ \\
& $(0.013)$ & $(1.457)$ \\
Share of Skill $t_{-1}$ & $0.087^{* * *}$ & $12.958^{* * *}$ \\
& $(0.013)$ & $(2.093)$ \\
Payment Incidents & -0.074 \\
& $-0.002^{* *} *$ & $(0.048)$ \\
Ile de France & $(0.001)$ & $-2.797 * * *$ \\
& $-0.012^{* *}$ & $(0.651)$ \\
\hline Observations & $(0.006)$ & 2,057 \\
Pseudo $R^{2}$ & 31,042 & 0.142 \\
\hline Sector FE & 0.113 & no \\
Year Effects & yes & yes \\
Firm FE & yes & yes \\
\hline Robust standard errors clustered at firm-level in parentheses. \\
$* * * * * *$ significantly different from 0 at $1 \%, 5 \%$ and $10 \%$ level.
\end{tabular}

using changes in market share to indicate changes in firm-level performance, we continue to find that negative shocks promote takeover of French targets by foreign multinationals. The estimated effect of firm-level shocks, as measured by changes in market share, is significant at high degrees of confidence. This fact further confirms that the timing of acquisition corresponds to targets being 'on sale' relative to their prior valuation.

\subsection{Export Networks and Geographical Differences}

The previous two sections considered how the export behavior of target firms, and changes to their productivity, influence cross-border M\&A behavior. Thus far we have not distinguished the export decisions that are due to endogenous investments by heterogeneous firms from the export decisions that are due to exogenous geographical advantages. Proposition 3 suggests that greater 
locational differences between target and acquiring firms enhance the probability of a foreign acquisition. In this section we take two different approaches to investigate how the cherry effect of export networks varies across geographical locations of acquiring firms. First, all domestic firms face the same costs associated with serving any foreign market. Thus, the export behavior of any target firm should be relatively less attractive to domestic acquirers, whose similar investments in export capacity make the target's network redundant, as compared to foreign acquirers. Second, countries that are far away from the domestic country are likely to face higher trade costs associated with serving markets proximate to the domestic country. Therefore, investments in export networks by domestic (French) targets should be more attractive to acquirers that are far away (non-European) relative to those that are nearby (European). ${ }^{29}$

\subsubsection{Domestic versus Foreign Acquisitions}

Figure 1 shows that the targets that are acquired by foreign multinational firms have relatively large export networks compared to other firms operating in the same sector. Another informative comparison is to consider the export networks among targets acquired by foreign versus domestic firms. On average, a French target that is acquired by a domestic firm (i.e., another French firm) serves 6.8 countries, whereas targets that are acquired by foreign multinationals serve 10.38 different countries prior to acquisition. In other words, the export network among targets that are acquired by foreign multinationals is approximately $65 \%$ larger on average, consistent with the predictions of the model.

In Table 6 we use a multinomial logit regression to estimate the relative effect of trade networks on the probabilities of foreign acquisition, domestic acquisition or no acquisition conditional on a full set of firm-level controls, plus sector and year effects. ${ }^{30}$ Table 6 reports the marginal effects of each regressor evaluated at the means from the entire sample. The excluded group in our regressions is the set of domestic acquisitions so that the marginal effects Table 6 can be directly

\footnotetext{
${ }^{29}$ Other factors such as language, legal origins and institutional quality have been shown to impact trade costs, in addition to distance. Since it it difficult to observe the actual trade costs incurred by individual firms, and across all countries, our strategy is to consider stark differences such as domestic versus foreign, and European versus nonEuropean.

${ }^{30}$ Within each year and 4-digit sector there is a small number of acquisitions observed, and even fewer observations of either domestic or foreign acquisitions. Given the small number of observations we incorporate 2-digit sector fixed effects, rather that 4-digit, when estimating the multinomial logit regression in Table 6.
} 
Table 6: Foreign versus Domestic Acquisition: Multinomial Logit Results

\begin{tabular}{|c|c|c|}
\hline & Non-Acquired & Foreign Acquisition \\
\hline $\ln (\text { Export Network })_{i t_{-2}}$ & $\begin{array}{l}-0.006 * * * \\
(0.002)\end{array}$ & $\begin{array}{l}0.004 * * * \\
(0.001)\end{array}$ \\
\hline$\Delta \ln (\mathrm{TFP})_{i t_{-1}}$ & $\begin{array}{l}0.025 * * * \\
(0.009)\end{array}$ & $\begin{array}{l}-0.009 * * \\
(0.004)\end{array}$ \\
\hline $\ln (\mathrm{TFP})_{i t_{-1}}$ & $\begin{array}{l}-0.038 * * * \\
(0.004)\end{array}$ & $\begin{array}{l}0.012 * * * \\
(0.001)\end{array}$ \\
\hline Share of Intangible ${ }_{i t_{-1}}$ & $\begin{array}{l}-0.078 * * * \\
(0.018)\end{array}$ & $\begin{array}{l}0.007 \\
(0.006)\end{array}$ \\
\hline Share of Skill ${ }_{i t_{-1}}$ & $\begin{array}{l}-0.108 * * * \\
(0.017)\end{array}$ & $\begin{array}{l}0.044 * * * \\
(0.005)\end{array}$ \\
\hline Payment Incidents ${ }_{i t_{-1}}$ & $\begin{array}{l}-0.000 \\
(0.000)\end{array}$ & $\begin{array}{l}-0.000 \\
(0.000)\end{array}$ \\
\hline Ile de France & $\begin{array}{l}0.031 * * * \\
(0.007)\end{array}$ & $\begin{array}{l}-0.007 * * * \\
(0.002)\end{array}$ \\
\hline Sector FE & yes & yes \\
\hline Year Effects & yes & yes \\
\hline $\begin{array}{l}\text { Observations } \\
\text { Pseudo } R^{2} \\
\text { Excluded group includ }\end{array}$ & ms that are acqu & ch acquirers. \\
\hline \multicolumn{3}{|c|}{$\begin{array}{l}\text { Robust standard errors clustered at firm-level in parentheses. } \\
* * *, * *, * \text { significance at } 1 \%, 5 \% \text { and } 10 \% \text { levels. }\end{array}$} \\
\hline
\end{tabular}

interpreted as effects relative to this excluded group.

Column (1) of Table 6 shows that smaller export networks and larger TFP gains are associated with a greater likelihood of not being acquired relative to the probability of a domestic acquisition. Thus, domestic firms are attracted, like foreign firms, to cherries for sale to some extent. However, column (2) shows that the "cherries for sale" effect is larger (as hypothesized) for foreign acquisitions. Greater export networks and TFP declines increase the probability of foreign acquisition relative to the probability of a domestic acquisition. In other words, large export and distribution networks among targets attract takeover bids (as prescribed by Proposition 1), but are significantly more likely to attract foreign takeover bids from firms that originate in other countries and face 
different trade costs (as prescribed by Proposition 3). ${ }^{31}$ It is interesting that we find that negative productivity shocks increase the likelihood of takeover by both foreign and domestic acquirers. The propensity of domestic acquirers to acquire primarily financially troubled and underperforming 'lemons' is consistent to previous evidence from US manufacturing in Lichtenberg \& Siegel (1987).

\subsubsection{Differences across Acquirer Origins}

The model above makes predictions about cross-border M\&A activity in a multi-country world. Given the differences in the costs of creating export networks across locations, the surplus generated from acquisition by a foreign multinational is much larger when it faces substantially different trade costs. The distribution of variable trade costs across countries is not observed directly. Yet, standard gravity models provide strong evidence that physical distance is a significant and robust barrier to trade; see for example Anderson \& van Wincoop (2003), among many others. Thus, multinationals that originate in countries far from the domestic market should value locally established export networks relatively more - in other words, export networks should be a stronger attractor of foreign investors who are more distant from the target firm's location.

To examine this, we explore whether an impact of export networks on the likelihood of acquisition by multinationals that originate from (near) European countries is lower than for those that originate from (far away) non-European countries. ${ }^{32}$ Similar to the differences between targets of domestic versus foreign acquisitions in the raw data, there are also substantial differences in the typical export networks among targets that are acquired by European versus non-European firms. Targets of acquisition by nearby European firms on average sell in 5.9 countries, while targets of non-European acquirers serve 14.0 different markets prior to acquisition. To verify the robustness of this difference in average export network size, Table 7 reports estimates obtained from a multi-

\footnotetext{
${ }^{31}$ Nocke \& Yeaple (2008) argue that the market potential of a target firm is an asset particular to its domestic market. While here we find that the locational advantage of domestic targets is tied to the potential to serve other foreign markets.

${ }^{32}$ There are 16 European members in the sample to which we add Liechtenstein, Monaco and the Netherlands and United Kingdom Possessions. (Austria, Belgium, Denmark, Finland, Germany, Greece, Ireland, Italy, Luxembourg, Monaco, Netherlands, Norway, Portugal, Spain, Sweden, United Kingdom). The group of non-European members is composed by Australia Canada, India, Israel, Japan, Lebanon, Singapore, South Korea, Switzerland, Taiwan, Tunisia, USA, and Venezuela.
} 
Table 7: European versus Non-European Foreign Acquisition: Multinomial Logit Results

\begin{tabular}{lll}
\hline & Non-Acquired & Non-European Acquisition \\
\hline $\ln (\text { Export Network })_{i t_{-2}}$ & $-0.007^{* * *}$ & $0.004^{* * *}$ \\
& $(0.002)$ & $(0.001)$ \\
$\Delta \ln (\mathrm{TFP})_{i t_{-1}}$ & $0.013^{* * *}$ & -0.003 \\
$\ln (\mathrm{TFP})_{i t_{-1}}$ & $(0.005)$ & $(0.002)$ \\
& $-0.031^{* * *}$ & $0.008^{* * *}$ \\
Share of Intangible ${ }_{i t_{-1}}$ & $(0.003)$ & $(0.001)$ \\
& $-0.023^{*}$ & 0.007 \\
Share of Skill ${ }_{i t_{-1}}$ & $(0.014)$ & $(0.007)$ \\
& $-0.115^{* * *}$ & $0.026^{* * *}$ \\
Payment Incidents & $(0.013)$ & $(0.007)$ \\
& $0.003^{* *}$ & $-0.002^{*}$ \\
Ile de France & $(0.001)$ & $(0.001)$ \\
& $0.018^{* * *}$ & 0.001 \\
& $(0.006)$ & $(0.003)$ \\
& & \\
\hline Sector FE & yes & yes \\
Year Effects & yes & yes \\
\hline Observations & & 0.1135 \\
Pseudo $R^{2}$ &
\end{tabular}

nomial logit regression with sector fixed-effects, where the omitted group is the set of target firms that acquired by European multinational firms. We include the full set of controls and report the marginal effects of each regressor evaluated at the entire sample mean.

In column (2) of Table 7 we find significant evidence (at the one percent level) that larger export networks increase the likelihood of being acquired by a far away non-European multinational firm, relative to the likelihood of being acquired by a nearby European multinational firm. The evidence in Table 7 is consistent with prediction in Proposition 3, suggesting that there are significant differences in role of exporting behavior by target firms in motivating cross-border M\&A across the location of acquiring firms.

The evidence in Table 7 also continues to support that multinational firms seek cherries for sale 
when engaging in cross-border acquisition activity. In column (1), we see that negative productivity shocks increase the likelihood that a firm is acquired by a foreign multinational relative to the likelihood of not being acquired; as evidenced by the positive coefficient on $\Delta \ln (\mathrm{TFP})_{i t_{-1}}$, increases in productivity raise the likelihood of non-acquisition relative to foreign takeover by European firms. And while negative productivity shocks promote acquisition activity by multinationals from both European and non-European countries, column (2) reports that the effect of these shocks does not differ significantly according to country of origin.

\section{Conclusion}

Cross-border mergers and acquisition constitute the primary mode of foreign direct investment. Understanding the motives to acquire affiliates in foreign countries, and understanding the effects of this substantial global economic activity, requires knowing what types of domestic targets multinationals seek to acquire. Here we have argued for two seemingly opposing incentives simultaneously motivate global M\&A activity.

In a multi-country world with differences in trade costs across locations, the formation of export networks endogenously creates (trade) cost synergies between firms from different locations. Firms with high initial levels of productivity are better able to establish costly export networks, generating larger surpluses from acquiring a target that was initially more productive. In other words, there are strong incentives for multinational firms to seek out targets that appear to be cherries in the domestic market. The incentives are even stronger for potential acquirers originating from locations far from the domestic market.

Firm productivities are constantly changing over time. When the performance of a domestic firm suffers, there is a greater surplus to be had by transferring control its stock of assets over to new management. Productivity losses among target firms provide an opportunity for multinational acquirers to obtain desired assets at relatively lower costs. Searching for such bargains lead multinational firms to seek out targets that appear to be cherries on sale.

We first constructed a model with endogenous export behavior, varying productivity within firms, and endogenous M\&A activity that provided several predictions about the patterns of crossborder acquisitions. We found strong evidence in from M\&A activity in France that foreign multi- 
nationals seek firms with strong prior export behavior and recent productivity losses. We also provided further evidence on the importance of export networks by contrasting acquisition patterns by domestic firms versus foreign multinationals, comparing foreign acquisitions across different countries of origin.

\section{References}

Aghion, P., Askenazy, P., Berman, N., Cette, G., \& Eymard, L. (2012). Credit constraints and the cyclicality of R\&D investment: evidence from france. Journal of the European Economics Association, 10(5), 1001-1024.

Anderson, J. E. \& van Wincoop, E. (2003). Gravity with gravitas: A solution to the border puzzle. The American Economic Review, 93(1), 170-92.

Arellano, M. \& Carrasco, R. (2003). Binary choice panel data models with predetermined variables. Journal of Econometrics, 115(1), 125-157.

Arkolakis, C. \& Muendler, M.-A. (2011). The extensive margin of exporting products: a firm-level analysis. NBER working paper 16641.

Arkolakis, C. \& Muendler, M.-A. (2013). Exporters and their products: a collection of empirical regularities. CESifo Economic Studies, 2013, 59(2), 223-248.

Arnold, J. \& Javorcik, B. (2009). Gifted kids or pushy parents? foreign direct investment and pland productivity in indonesia. Journal of International Economics, 79(1), 42-53.

Bernard, A. B., Eaton, J., Jensen, J. B., \& Kortum, S. (2003). Plants and productivity in international trade. The American Economic Review, 93(4), 1268-1290.

Bernard, A. B. \& Jensen, J. B. (1999). Exceptional exporter performance: cause, effect or both? Journal of International Economics, 47(1), 1-25.

Bernard, A. B. \& Jensen, J. B. (2004). Why some firms export. Review of Economics and Statistics, $86(2), 561-569$.

Bernard, A. B., Redding, S., \& Schott, P. (2011). Multi-product firms and trade liberalization. The Quarterly Journal of Economics, forthcoming. Princeton University working paper.

Bernard, A. B. \& Wagner, J. (2001). Export entry and exit by german firms. Welktwirtschaftliches Welktwirtschafrliches Archiv, 137(H.1), 105-123.

Blonigen, B. A., Davies, R. B., Waddell, G. R., \& Naughton, H. (2007). Fdi in space: Spatial autoregressive relationships in foreign direct investment. European Economic Review, 51(5), $1303-25$. 
Blonigen, B. A. \& Taylor, C. T. (2000). R\&d intensity and acquisitions in high-technologies: evidence from the us electronic and electrical equipment industries. Journal of Industrial Economics, 48(1), 47-70.

Bricongne, J.-C., Fontagné, L., Gaulier, G., Tablioni, D., \& Vicard, V. (2012). Firms and the global crisis: French exports in the turmoil. Journal of International Economics, 87(1), 134-46.

Campa, J. M. (2004). Exchange rates and trade: how important is hysteresis in trade? European Economic Review, 48(3), 527-548.

Criscuolo, C. \& Martin, R. (2009). Multinationals and u.s. productivity leadership: Evidence from great britain. Review of Economics and Statistics, 91(2), 263-81.

Desai, M. A., Foley, C. F., \& Hines Jr., J. R. (2004). A multinatinoal perspective on capital structure and internal capital markets. The Journal of Finance, 59(6), 2451-2487.

Ekholm, K., Forslid, R., \& Markusen, J. R. (2007). Export-platform foreign direct investment. Journal of the European Economics Association, 5(4), 776-95.

Fich, E. M., Cai, J., \& Tran, A. L. (2011). Stock option grants to target ceos during private merger negotiations. Journal of Financial Economics, 101, 413-30.

Foster, L., Haltiwanger, J. C., \& Syverson, C. (2008). Reallocation, firm turnover and efficiency: selection on productivity or profitability. The American Economic Review, 98(1), 394-425.

Gorton, G., Kahl, M., \& Rosen, R. J. (2009). Eat or be eaten: a theory of mergers and firm size. Journal of Finance, 64(5), 1291-1344.

Guadalupe, M., Kuzmina, O., \& Thomas, C. (2012). Innovation and foreign ownership. The American Economic Review, 102(7), 3594-3627.

Hanson, G. H., Mataloni, R. J., \& Slaughter, M. J. (2001). Expansion strategies of u.s. multinational firms. In D. Rodrik \& S. Collins (Eds.), Brookings Trade Forum 2001. Washington, D.C.: Brookings.

Harford, J. (2005). What drives merger waves? Journal of Financial Economics, 77(3), 529-60.

Head, K. \& Ries, J. (2008). Fdi as an outcome of the market for corporate control: theory and evidence. Journal of International Economics, 74(1), 2-20.

Heitzman, S. (2011). Equity grants to target ceos during deal negotiations. Journal of Financial Economics, 102, 251-71.

Helpman, E., Melitz, M. J., \& Rubinstein, Y. (2008). Estimating trade flows: Trading partners and trading volumes. Quarterly Journal of Economics, 123, 441-87.

Heyman, F., Sjoholm, F., \& Tinvall, P. G. (2007). Is there really a foreign ownership premium? evidence from matched employer-employee data. Journal of International Economics, 73(2). 
Honore, B. E. \& Lewbel, A. (2002). Semiparametric binary choice panel data models without strictly exogenous regressors. Econometrica, 70(5), 2053-2063.

Honore, B. E. \& Tamer, E. (2006). Bounds on parameters in panel dynamic discrete choice models. Econometrica, 74(3), 611-629.

Impullitti, G., Irarrazabal, A. A., \& Opromolla, L. D. (2013). A theory of entry into and exit from export markets. Journal of International Economics, 90(1), 75 - 90.

Lai, H. \& Zhu, S. C. (2006). U.s. export and multinational production. Review of Economics and Statistics, 88(3), 531-548.

Lee, D. (2011). Cross-border mergers and acquisitions with heterogeneous firms: technology vs. market motives. mimeo University of Oregon.

Lichtenberg, F. R. \& Siegel, D. (1987). Productivity and changes of ownership in manufacturing plants. Brookings Papers on Economic Activity, 1987(3), 643-83.

Maksimovic, V. \& Phillips, G. (2009). Do conglomerate firms allocate resources inefficiently across industries? theory and evidence. Journal of Finance, 64(2), 721-67.

Manne, H. G. (1965). Mergers and the market for corporate control. Journal of Political Economy, 73(110-20).

Neary, J. P. (2007). Cross-border mergers as instruments of comparative advantage. Review of Economic Studies, 74(4), 1229-57.

Nocke, V. \& Yeaple, S. R. (2007). Cross-border mergers and acquisitions versus greenfield foreign direct investment: the role of firm heteroeneity. Journal of International Economics, 72(2), 336-365.

Nocke, V. \& Yeaple, S. R. (2008). An assignment theory of foreign direct investment. Review of Economic Studies, 75(2), 529-557.

Olley, G. S. \& Pakes, A. (1996). The dynamics of productivity in the telecommunications industry. Econometrica, 64, 1263-1298.

Ramondo, N. (2009). Foreign plants and industry productivity: Evidence from chile. Scandinavian Journal of Economics, 111(4), 789-809.

Rhodes-Kropf, M. \& Robinson, D. T. (2008). The market for mergers and the boundaries of the firm. Journal of Finance, 63(3), 1169-1211.

Roberts, M. J. \& Tybout, J. R. (1997). The decision to export in Colombia: an empirical model of entry with sunk costs. The American Economic Review, 87(4), 545-564.

Syverson, C. (2004). Market structure and productivity: a concrete example. Journal of Political Economy, 112(6), 1181-1222. 
UNCTAD (2000). World investment report. Technical report, United Nations, New York, NY.

Wooldridge, J. M. (2005). Simple solutions to the initial conditions problem in dynamic, nonlinear panel data models with unobserved heterogeneity. Journal of Applied Econometrics, 20, $39-54$.

Yang, L. (2008). The real determinants of asset sales. Journal of Finance, 63(5), 2231-62.

Yeaple, S. R. (2003). The complex integration strategies of multinationals and cross-country dependencies in the structure of foreign direct investment. Journal of International Economics, 60(2), 293-314. 